\title{
EXPERIMENTAL REINTRODUCTION OF WOODY DEBRIS ON THE WILLIAMS RIVER, NSW: GEOMORPHIC AND ECOLOGICAL RESPONSES
}

\author{
ANDREW P. BROOKS, ${ }^{\mathrm{a} *}$ PETER C. GEHRKE, ${ }^{\mathrm{b} \dagger}{ }^{\dagger} \mathrm{JOHN}^{\mathrm{D}}$. JANSEN ${ }^{\mathrm{c}}$ and TIM B. ABBE ${ }^{\mathrm{d}}$ \\ a Centre for Riverine Landscapes, Griffith University, Nathan, QLD 4111, Australia \\ b NSW Fisheries Office of Conservation, Port Stephens Fisheries Centre, Private Bag 1, Nelson Bay, NSW 2315, Australia \\ ${ }^{\mathrm{C}}$ School of Geosciences, University of Wollongong, NSW 2522, Australia \\ d Hererra Environmental Consultants, Inc. 2200 Sixth Ave, Suite 1100, Seattle, WA 98121-1820, USA
}

\begin{abstract}
A total of $436 \operatorname{logs}$ were used to create 20 engineered log jams (ELJs) in a $1.1 \mathrm{~km}$ reach of the Williams River, NSW, Australia, a gravel-bed river that has been desnagged and had most of its riparian vegetation removed over the last 200 years. The experiment was designed to test the effectiveness of reintroducing woody debris (WD) as a means of improving channel stability and recreating habitat diversity. The study assessed geomorphic and ecological responses to introducing woody habitat by comparing paired test and control reaches. Channel characteristics (e.g. bedforms, bars, texture) within test and control reaches were assessed before and after wood placement to quantify the morphological variability induced by the ELJs in the test reach. Since construction in September 2000, the ELJs have been subjected to five overtopping flows, three of which were larger than the mean annual flood. A high-resolution three-dimensional survey of both reaches was completed after major bed-mobilizing flows. Cumulative changes induced by consecutive floods were also assessed. After 12 months, the major geomorphologic changes in the test reach included an increase in pool and riffle area and pool depth; the addition of a pool-riffle sequence; an increase by $0.5-1 \mathrm{~m}$ in pool-riffle amplitude; a net gain of $40 \mathrm{~m}^{3}$ of sediment storage per $1000 \mathrm{~m}^{2}$ of channel area (while the control reach experienced a net loss of $15 \mathrm{~m}^{3} / 1000 \mathrm{~m}^{2}$ over the same period); and a substantial increase in the spatial complexity of bed-material distribution. Fish assemblages in the test reach showed an increase in species richness and abundance, and reduced temporal variability compared to the reference reach, suggesting that the changes in physical habitat were beneficial to fish at the reach scale. Copyright (C) 2004 John Wiley \& Sons, Ltd.
\end{abstract}

KEY WORDS: river rehabilitation; woody debris; geomorphic recovery; complex response; meso-habitat; micro-habitat

\section{INTRODUCTION}

Woody debris (WD) is increasingly recognized as an important component of physical habitat in rivers. It is also widely acknowledged that the volume of wood presently found in rivers is a small fraction of that existing prior to human intervention (Triska, 1984; Gippel et al., 1992; Maser and Sedell, 1994; Abbe and Montgomery, 1996; Treadwell et al., 1999; Abbe, 1999; Brooks, 1999a; Brooks et al., in press). The practice of desnagging, or removal of in-stream WD, has been widespread in Australian rivers throughout the last 200 years. In many rivers almost the entire natural WD load has been removed (e.g. Gippel et al., 1992; Treadwell et al., 1999). The Australian experience reflects similar situations throughout the world, notably North America and Europe, where very few rivers retain WD loadings comparable with pre-agricultural forested conditions (e.g. Triska, 1984; Maser and Sedell, 1994; Abbe, 1999; Brooks, 1999a,b). Typically, channels that have been subjected to desnagging and other direct channel disturbances have experienced morphological changes such as incision, expansion, increased sediment flux and morphological homogenization. It has been hypothesized that the loss of physical habitat associated with WD, combined with geomorphic homogenization, or loss of in-stream habitat complexity at the meso- and microhabitat scales, is now a limiting factor on the productivity and diversity of aquatic ecosystems (Meffe \& Sheldon, 1988; Shields and Smith, 1992; Maddock, 1999; Crook and Robertson, 1999).

\footnotetext{
* Correspondence to: A. P. Brooks, Centre for Riverine Landscapes, Griffith University, Nathan, QLD 4111, Australia.

E-mail: Andrew.Brooks@griffith.edu.au

${ }^{\dagger}$ Present address: CSIRO Land and Water, 120 Meiers Road, Indooroopilly, QLD 4068, Australia.
} 
In Australia, issues associated with WD and riparian vegetation are now viewed as major river management concerns (see Lovett, 2000). There is currently a nationwide movement to rehabilitate channels (see Rutherfurd et al., 2000), and increasing WD loads is regarded as integral to rehabilitation. In this study an experimental approach has been adopted to assess the geomorphic and ecological effects of reintroducing WD within a $1100 \mathrm{~m}$ reach of a gravel-bed river in southeastern Australia. The work aims to assess the performance of individual log structures, as well as their combined effects at the reach scale. The study was designed as a standard Before/After/Control/Impact (BACI) experiment, with a single control reach upstream of the test reach. This paper presents responses in reach-scale channel geomorphology, character of bed materials and fish assemblages, 12 months after WD reintroduction.

\section{STUDY AREA}

A section of the Williams River at Munni was selected as the test reach (Figure 1), based on a broad range of criteria including its past history of desnagging, good anecdotal and archival data on the management history and channel changes, and good access and visibility for use as an educational facility for the local community (Table I). The test reach encompasses a full bedrock meander, while the control reach $3.1 \mathrm{~km}$ upstream represents half of an equivalent meander. Most importantly, the two study sites are characterized by a discontinuous floodplain river style (Brierley et al., 2002) typical of many coastal gravel-bed rivers in eastern Australia. Thus, lessons

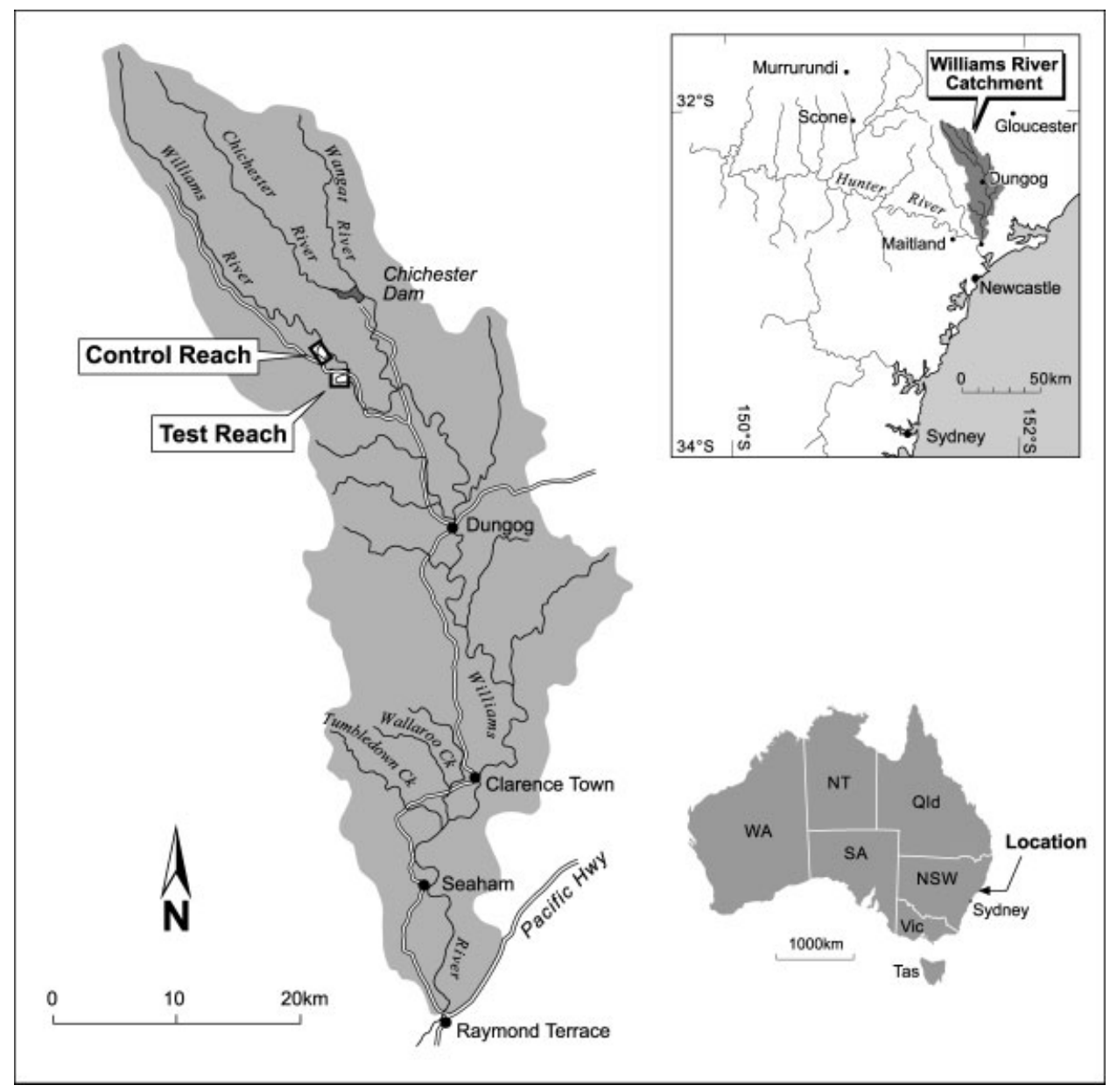

Figure 1. Study area location map 
Table I. Study site selection criteria

(1) Relatively homogeneous section of channel approximately $1 \mathrm{~km}$ in length incorporating at least three pool-riffle segments.

(2) Alluvial or semi-alluvial river reaches known to have experienced desnagging within the last 50 years.

(3) Channels that as a result of (2) and other disturbances (such as riparian vegetation clearance and grazing) are known to have experienced increased sediment flux.

(4) Local sediment supply upstream of each reach should be comparable.

(5) Channel dimensions sufficiently small to allow measurable channel changes from input of manageable volumes of timber.

(6) Natural channel 'recovery' should be sufficiently advanced such that riparian vegetation is not a limiting factor regarding bank stability and aquatic ecology.

(7) Close to an operating flow gauge, with a sufficiently lengthy record.

(8) A geomorphically comparable control reach within a few kilometres upstream of the test reach-not separated by major tributary inputs - both sharing a common disturbance and land use history.

learned here have a wider significance for rehabilitation strategies elsewhere. The presence of active bank erosion and large mobile gravel bars immediately upstream of each reach suggests sediment supply is comparable for the two reaches and that local sediment supply was not limiting during the experimental period.

The baseline attributes of the two study reaches include comparable channel dimensions, bed materials and flow characteristics. The two reaches drain upstream areas of $185 \mathrm{~km}^{2}$ and $180 \mathrm{~km}^{2}$ respectively (Figure 1). The Munni test reach measured $1100 \mathrm{~m}$ in length with a reach bed slope of 0.0025 and median clast size of $76 \mathrm{~mm}(n=1800)$. The $550 \mathrm{~m}$ control reach had a bed slope of 0.0017 and median clast size of $77 \mathrm{~mm}(n=400)$. Hydrological attributes of the study reaches were determined from the flow gauge at Tillegra Bridge, $5.1 \mathrm{~km}$ downstream of the Munni test reach (catchment area $194 \mathrm{~km}^{2}$ ). The mean annual flood (arithmetic mean of the annual flood series, $1931-1993$ ) is $170 \mathrm{~m}^{3} / \mathrm{s}$. Based on a cross-section defined by alluvial banks in the test reach, 'bankfull discharge' equals $800 \mathrm{~m}^{3} / \mathrm{s}$, a flood with a recurrence exceeding 100 years. The large capacity is interpreted to stem from channel and riparian zone disturbance since European settlement, particularly desnagging (cf. Erskine and White, 1999; Brooks, 1999a,b; Brooks et al., in press).

\section{Williams River disturbance history}

Clearance of the floodplain forests along the Williams River valley accompanied the spread of cropping and grazing activities in the mid-nineteenth century. According to the first survey of the river (White, 1829, 1830, 1836), the floodplains and banks of the Williams River upstream of the estuary supported 'thick brush' (a local term for subtropical rainforest), while the hillslopes were heavily timbered with either dry or wet sclerophyll eucalypt forest depending on aspect. By 1832, large land grants extended up the Williams River beyond the study reaches (Ford, 1995). While the high country still supports stands of Nothofagus-dominated cool-temperate rainforest, few remnants of the pre-settlement subtropical rainforest communities remain at lower elevations. Widespread forest clearance during the initial settlement phase presumably increased runoff and flood peak discharges (Bosch and Hewlett, 1982; Cornish, 1993; Erskine, 1998).

\section{'River training'}

Commencing in the mid-1950s, the Williams River channel has been actively modified under the guise of flood mitigation schemes and 'river training' (Reddoch and Milston, 1953; Reddoch, 1957; Rankin, 1980a,b, 1982). With the aim of maximizing both channel capacity and flow velocity, 'channel improvements' have been imposed including extensive desnagging (i.e. removal of log steps and clearance of in-channel vegetation from bars and banks). Erskine (1998) reported extraction of at least 8000 trees and logs above the tidal limit (i.e. about $86 \mathrm{~km}$ of channel) between 1954 and 1991. However, owing to incomplete records, such figures represent a minimum. Available evidence suggests river works in the reach upstream of Tillegra Bridge began in March 1966 (Erskine 1998), and anecdotal evidence (A. Daughtrey, Munni Dairy manager, personal communication, 2000) describes 'river gangs' spending three weeks removing logs from the test reach alone in the 1960s. The hard won logs were then stacked in large piles on the adjacent floodplain and burnt. 
Various engineering works were implemented to address the ensuing channel instability and provide a stable channel alignment. The removal of flow obstructions partially blocking the channel was central, as these were held to cause erosion via flow deflection into banks. The works included channel realignment by bulldozing channel bars, removal of gravel armour and boulders from riffles, installation of wire mesh fences and planting of 48000 exotic trees (including 40000 willows).

\section{Recent bed level changes}

While ongoing recovery of riparian vegetation in the Williams River has reduced bank erosion, major bed instability continues to be a key concern of both river managers and land owners, particularly erosion of riffles and infilling of low-flow pools (Erskine, 1998; E. and N. Smith, Munni landowners, personal communication, 2000). Erskine (1998) pointed out that the cease-to-flow height at the Tillegra gauge fell by up to $0.85 \mathrm{~m}$ after 1955 . Repeated cross-section surveys (1931-1980) indicate that while the bed's thalweg has shifted $15 \mathrm{~m}$ laterally, no vertical change is recorded. This suggests that the pool here is floored with bedrock, and thus, the decline in cease-to-flow height reported by Erskine (1998) reflects erosion of the downstream riffle crest, not broad-scale incision.

It is speculated that present oversized channel dimensions reflect channel and riparian zone disturbance since European settlement, and that channel expansion accelerated with the onset of desnagging in the 1960s coincident with a series of large floods (cf. Erskine and White, 1996; Brooks, 1999a,b; Brooks et al., in press). In support of this notion, the 1946 flood (the flood of record), which preceded desnagging, did not induce riffle crest lowering at Tillegra gauge. Photographic evidence reveals the oversized channel seen today at Munni was extant throughout the 1960s, 1970s and 1980s, but this contrasts with the significantly smaller channel of 1940. This is consistent with recent findings on the links between bed stability and woody debris (Montgomery et al., 1996; Brooks and Brierley, 2002).

\section{METHODS}

\section{Baseline reach characterization}

An appraisal of basic geomorphic attributes of the study reaches contributed to the design of the reach-based rehabilitation strategy and provided a baseline from which to measure future success. Two types of data were collected: qualitative mapping of geomorphic and hydrogeomorphic units within the reach (e.g. Church, 1992), and quantitative data, including a detailed three-dimensional survey of reach morphology, and measurement of bed material texture.

Definition and mapping of the geomorphic and hydrogeomorphic units within each reach provided a template for the ecological monitoring (Figures 2 and 3). Delineation of the in-channel units was based on geomorphic and hydraulic factors (after Raven et al., 1998; Thomson et al., 2001). As the spatial scales of habitat units are species specific, two scales of resolution were adopted: a coarse resolution assessment for the fish, and a finer resolution assessment for mussels (not reported here) (Figures 3 and 4). However, even the finer resolution map has been kept relatively simple. For instance, all bars are grouped together, despite the range of bar types, sizes and degrees of vegetation cover, and pools are consolidated into two types: lateral scour pools and bedrock forced pools. Of course, such qualitative methods of delineating space are open to subjective error. However, we have aimed to keep the procedure as simple as possible, with a view to the specific objectives of this project.

\section{Rehabilitation strategy}

In September 2000, 20 engineered log jams (ELJs) incorporating 436 logs were constructed in the test reach at Munni. The ELJ structures included both flow deflection structures along the river's banks and channel-spanning grade control structures intended to prevent channel incision and to trap additional sediment within the test reach. All of the structures were built without artificial anchoring such as cabling or imported ballast. Figure 5 shows the location of the structures within the test reach.

The rehabilitation strategy was designed to address specific reach- and subreach-scale geomorphic 'problems' arising from larger-scale land use and management impacts. Three key management problems were identified in 


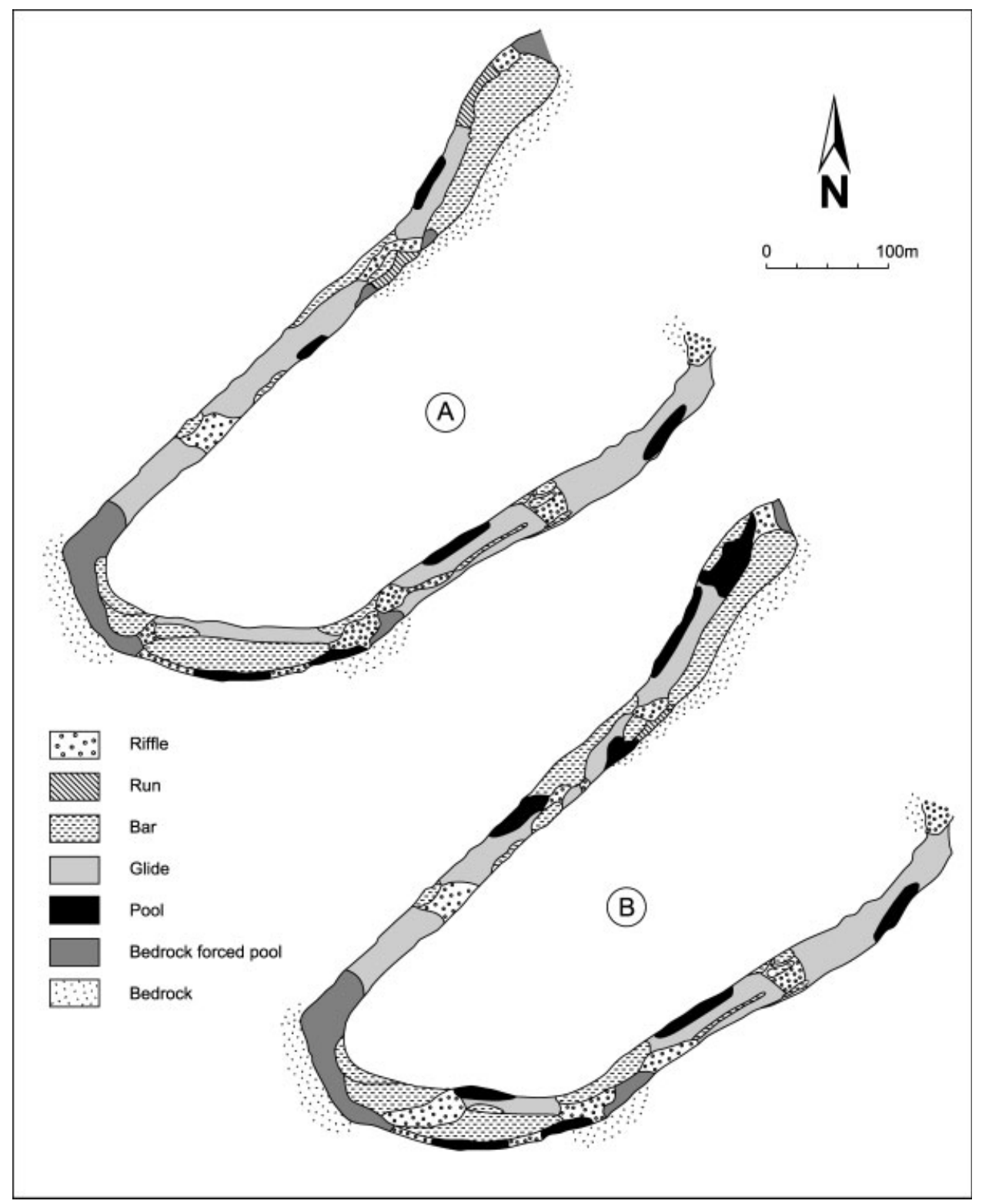

Figure 2. Test reach hydrogeomorphic units: A, before treatment; B, after treatment. Note the additional riffle-pool sequence about one-quarter of the way down the test reach in B and the marked increase in both pool and riffle habitat types

the study reaches: (1) bed homogenization (i.e. the loss or degradation of meso-habitat units such as riffle-pool sequences through flattening of riffles and infilling of pools); (2) excessive bed mobility and high sediment flux; and (3) local bank erosion, particularly in the areas downstream of bedrock-forced pools where gravel bars accrete and deflect the channel thalweg laterally (Brooks et al., 2001).

A range of ecological implications is hypothesized to stem from each of these geomorphic problems: (1) the loss of physical habitat and habitat diversity both at the meso- and micro-habitat unit scale; (2) a loss of ecosystem processes as a result of (1), e.g. hyporheic zone function; (3) a deficit of viable habitat for some benthic species (e.g. mussels) given the high bed shear stresses and bed material mobility; (4) increased bank erosion raises sediment supply to the river (both fine and coarse fractions) increasing turbidity during flood flows, further exacerbating problems (1)-(3). 


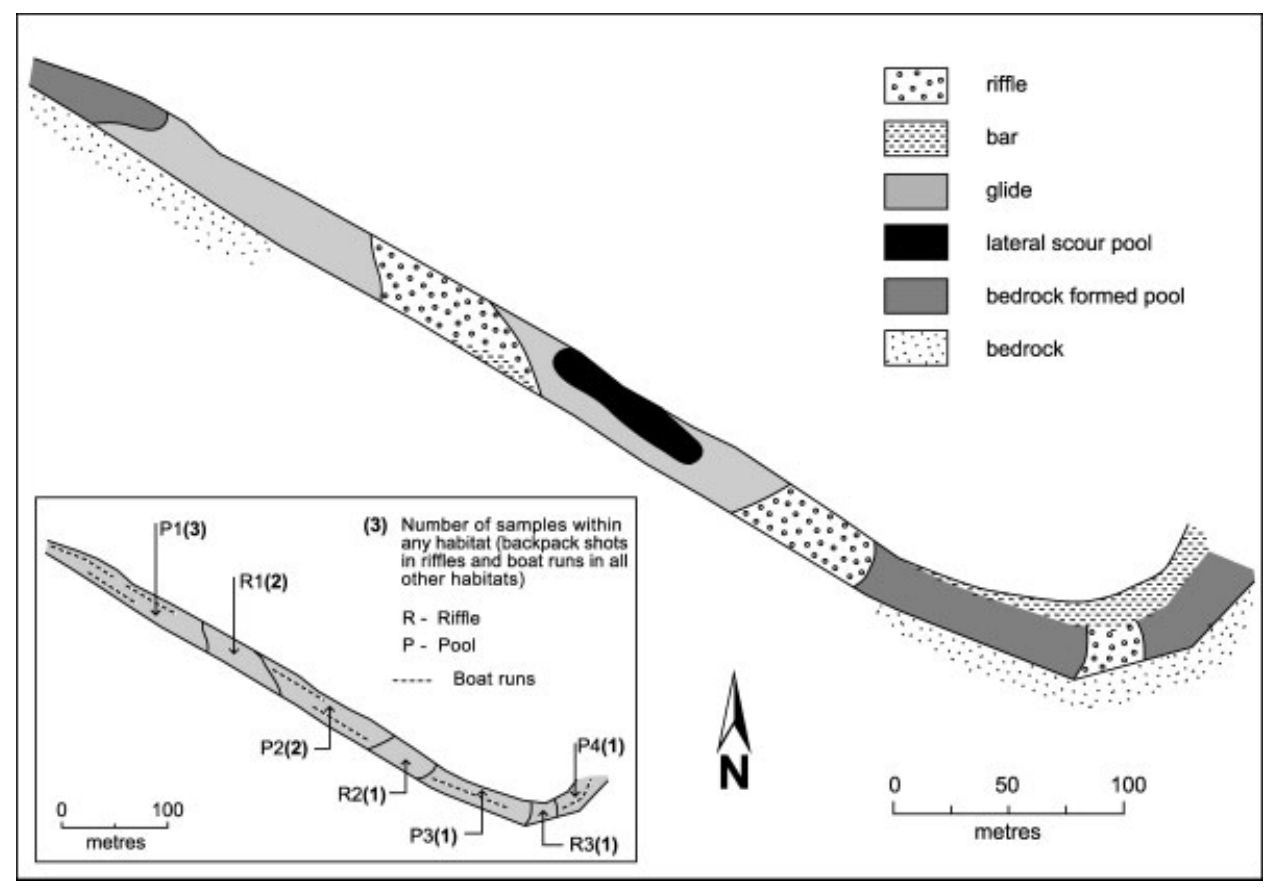

Figure 3. Control reach hydrogeomorphic units, and key map for ecological sampling (inset). Geomorphic unit distribution is unchanged for the same period represented in Figure 2B

\section{Reach-scale principles of WD rehabilitation}

Having described the basic geomorphic attributes of the study reaches within the context of broader catchment and channel disturbance, the broad aim of the rehabilitation strategy was to improve channel stability and maximize geomorphic complexity and hence habitat diversity. More specifically, the reach strategy was devised in accordance with the following guiding principles: (1) the strategy should enhance and stabilize incipient or transient geomorphic units, within a framework that accounts for reach and catchment setting and reach- and catchment-scale disturbance processes; (2) in-stream rehabilitation using WD should operate in conjunction with efforts to optimize the ecological and structural integrity of the riparian vegetation corridor; (3) the strategy should aim to minimize sediment flux and maximize the potential for increasing habitat complexity (it is assumed that sediment flux is elevated as a result of past land-use and management practices); (4) within the constrictions placed by flood hazards associated with local infrastructure, hydraulic roughness (and thus energy dissipation) should be maximized within the channel through increased WD roughness, form roughness, and in-channel vegetation; (5) when combating bank erosion, causal mechanisms should be treated as well as the traditional treatment of symptoms of erosion via revetment or bank hardening (in large part this will involve addressing bed instability and deflecting flow away from eroding banks); (6) in situations where the channel is incised or enlarged as a result of disturbance processes, and hence local flooding is not a key concern, channel contraction should be induced as a mechanism to facilitate pool scour; (7) where possible pool scour should be maximized by deflecting flow towards resistant banks, particularly bedrock or well-vegetated areas (however, where flow is deflected into hard banks, to prevent initiation of new bank erosion further downstream, bank reinforcement measures must also be taken in the zones receiving the deflected flow).

\section{Log structures}

The ELJ structures were modelled on naturally occurring log jams (e.g. Abbe et al., 1997; Abbe, 2000). Field observations indicate that such features can remain stable for thousands of years in natural settings (Abbe, 2000), although this varies considerably between species and with local sediment and groundwater conditions. Under 


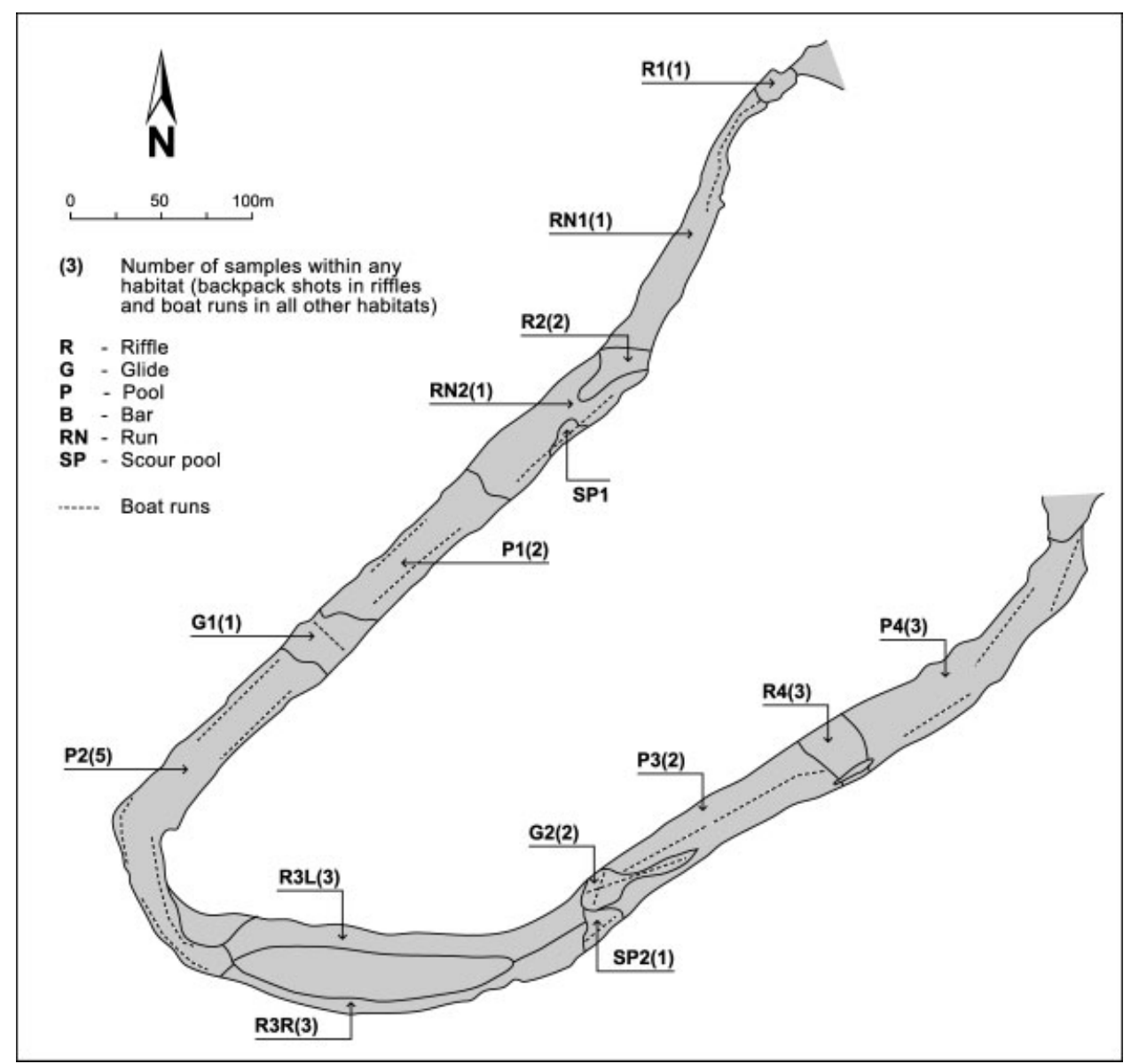

Figure 4. Test reach key map for ecological sampling

natural conditions, the stability of the log jams is a function of the burial of the key log root wads into the river bed, the interlocking of accreted logs within the structure, ballast associated with subsequent sediment deposition, and vegetation, which tends to colonize the whole structure. The same principles for structural stability were used in the engineered versions; hence, logs with intact root wads were used for the primary structural elements of all ELJs.

Logs used were primarily eucalypt logs with root wads (totalling $350 \mathrm{t}$ of wood), and were placed in 20 ELJs within the $1100 \mathrm{~m}$ test reach (Figure 5). Structural stability analysis followed a combination of the approaches adopted by Abbe et al. (1997), D'Aoust and Millar (1999), Abbe (2000) and Shields et al. (1995, 2000). Four types of ELJ were designed for the test reach: deflector jams, bar apex jams, bank revetment structures and log-sill bed control structures. Table II presents the summary attributes of each ELJ shown in Figure 5. The volume of wood introduced to the test reach equates with an average reach loading of $0.014 \mathrm{~m}^{3} / \mathrm{m}^{2}$, which falls within the guidelines outlined in Marsh et al. (1999) for temperate rivers in southeast Australia. Following is a general description of each type with an outline of their primary purpose.

Deflector jams (DFJs 1-8). These are bank-attached, multi-layered, impermeable log jams with gravel back-fill for ballast (Figure 6A). Basal key logs are buried to a depth greater than the predicted scour depth for the design flow. The magnitude of the log jams varies depending on the specific location; however, where the primary role is bank erosion protection, they should extend to at least half bankfull height (Abbe et al., 1997). The main geomorphic and engineering uses of these structures are: (1) as an alternative to traditional rock revetment for protection from bank erosion; (2) a mechanism for inducing channel contraction, through direct modification of the channel cross-section (with the structure) and via enhanced sedimentation on and around the structure, which further constricts the cross-section; (3) a mechanism for redirecting flow to maximize pool scour and energy 


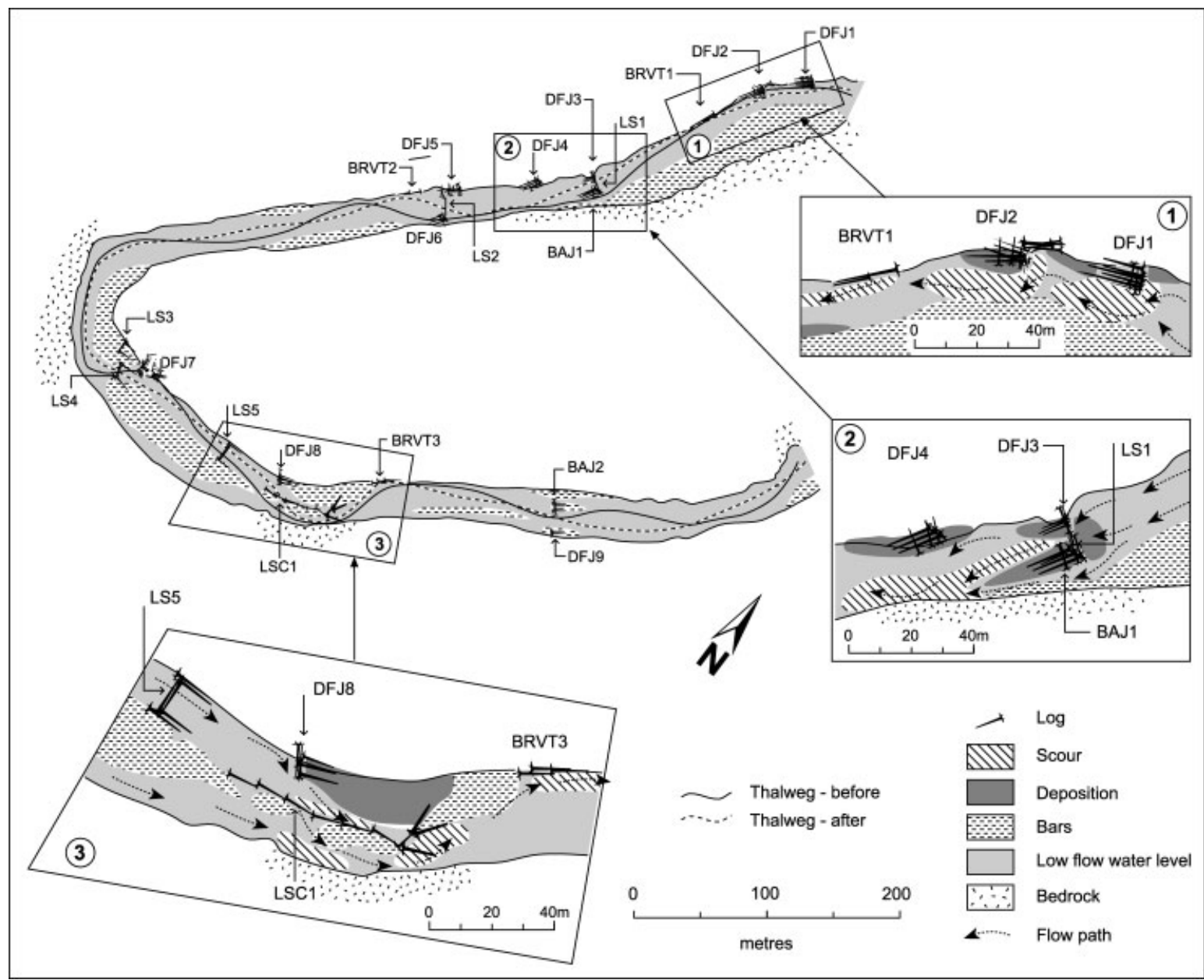

Figure 5. Map showing the locations of the 20 ELJs constructed within the test reach. DFJ = deflector jam; BRVT= bank revetment structure; $\mathrm{LS}=\log$ sill; $\mathrm{LSC}=\log$ sill complex; BAJ $=$ bar apex jam. Also shown are the predicted zones of scour and deposition

dissipation. To achieve the first objective the structures are normally located on concave eroding banks where they actively deflect the channel thalweg away from the bank, thereby reducing the force driving the erosion. Deflector jams also provide toe-revetment, and hence aid in the geotechnical stabilization of the bank. The length of bank protected from erosion through thalweg deflection is a function of the extent of log jam protrusion into the flow. Depending on the flow's angle of incidence, the length of bank protection is three to five times the width of flow obstruction (e.g. Klingeman et al., 1984; Miller et al., 1984). In addition to these primary geomorphic objectives, these structures impart a number of habitat benefits, including complex fish habitat within and around the structures (Crook and Robertson, 1999), substrate for biofilms (Crook and Robertson, 1999), and increased lateral hyporheic zone exchange (Findlay, 1995) in the scallops scoured into the bars opposite the structures (A. Boulton, University of New England, personal communication, 2003).

Bank revetment structures (BRVT1-3). These are layered log-crib type structures in which the logs lie parallel to the flow along low banks or inset benches (Figure 6B). Logs cover the majority of the bank face exposed to flow and the extent of bank protection depends on the height of the log jam; hence, this type of structure tends to be only used on relatively low banks. Basal logs are keyed into the bed for stability. The function of these structures is: (1) as bank erosion protection via buttressing of the bank toe, physical hardening of the bank face, and increased bank roughness particularly associated with the protruding root wads; (2) habitat enhancement via creation of bank structure akin to an overhang, as well as complex micro-habitat within and around the logs. 
Table II. Log structure characteristics for the Munni test reach

\begin{tabular}{|c|c|c|c|c|c|c|}
\hline Structure ID & $\begin{array}{l}\text { No. } \\
\operatorname{logs}\end{array}$ & $\begin{array}{l}\text { Wood } \\
\text { vol. }\left(\mathrm{m}^{3}\right)\end{array}$ & $\begin{array}{l}\text { Approx. structure } \\
\text { vol. }\left(\mathrm{m}^{3}\right)\end{array}$ & $\begin{array}{l}\text { Area protruding } \\
\text { into flow }\left(\mathrm{m}^{2}\right)\end{array}$ & $\begin{array}{l}\text { Calibrated } n(\text { pre- } L W D \\
\left.\quad \text { for } \mathrm{Q}=352 \mathrm{~m}^{3} / \mathrm{s}\right)\end{array}$ & $\begin{array}{c}\text { Modified } \\
n(\text { post }-L W D)\end{array}$ \\
\hline DFJ1 & 59 & 53.4 & 224 & 25.0 & 0.030 & 0.040 \\
\hline DFJ2 & 59 & 43.7 & 231 & 30.6 & 0.030 & 0.040 \\
\hline BRVT1 & 7 & 8.6 & 12 & 2.3 & 0.030 & 0.033 \\
\hline DFJ3 & 6 & 6.6 & 26 & 4.8 & 0.035 & 0.035 \\
\hline LS1 & 3 & 2.6 & 2.6 & na & 0.035 & 0.035 \\
\hline BAJ1 & 24 & 18.3 & 65 & 11.9 & 0.035 & 0.035 \\
\hline DFJ4 & 25 & 19.5 & 104 & 9.4 & 0.035 & 0.038 \\
\hline DFJ5 & 28 & 23.8 & 106 & 8.4 & 0.035 & 0.039 \\
\hline DFJ6 & 40 & 40.2 & 132 & 18.0 & 0.035 & 0.040 \\
\hline LS2 & 3 & 2.1 & 2.1 & na & 0.035 & 0.040 \\
\hline BRVT2 & 7 & 12.8 & 14 & 1.3 & 0.030 & 0.032 \\
\hline LS3 & 5 & 4.5 & 4.5 & na & 0.090 & 0.090 \\
\hline DFJ7 & 109 & 91.9 & 260 & 35.0 & 0.060 & 0.070 \\
\hline LS4 & 5 & 6.2 & 6.2 & na & 0.060 & 0.070 \\
\hline LS5 & 6 & 4.9 & 4.9 & na & 0.060 & 0.060 \\
\hline DFJ8 & 11 & 9.6 & 19 & 3.5 & 0.050 & 0.053 \\
\hline LSC1 & 14 & 16.7 & 16.7 & na & 0.050 & 0.053 \\
\hline BRVT3 & 9 & 10.9 & 17 & 1.5 & 0.045 & 0.047 \\
\hline BAJ2 & 13 & 10.6 & 55 & 5.5 & 0.065 & 0.069 \\
\hline DFJ9 & 3 & 2.5 & 11 & 1.0 & 0.065 & 0.069 \\
\hline Total & 436 & 389 & 1277 & na & 0.046 & 0.049 \\
\hline
\end{tabular}
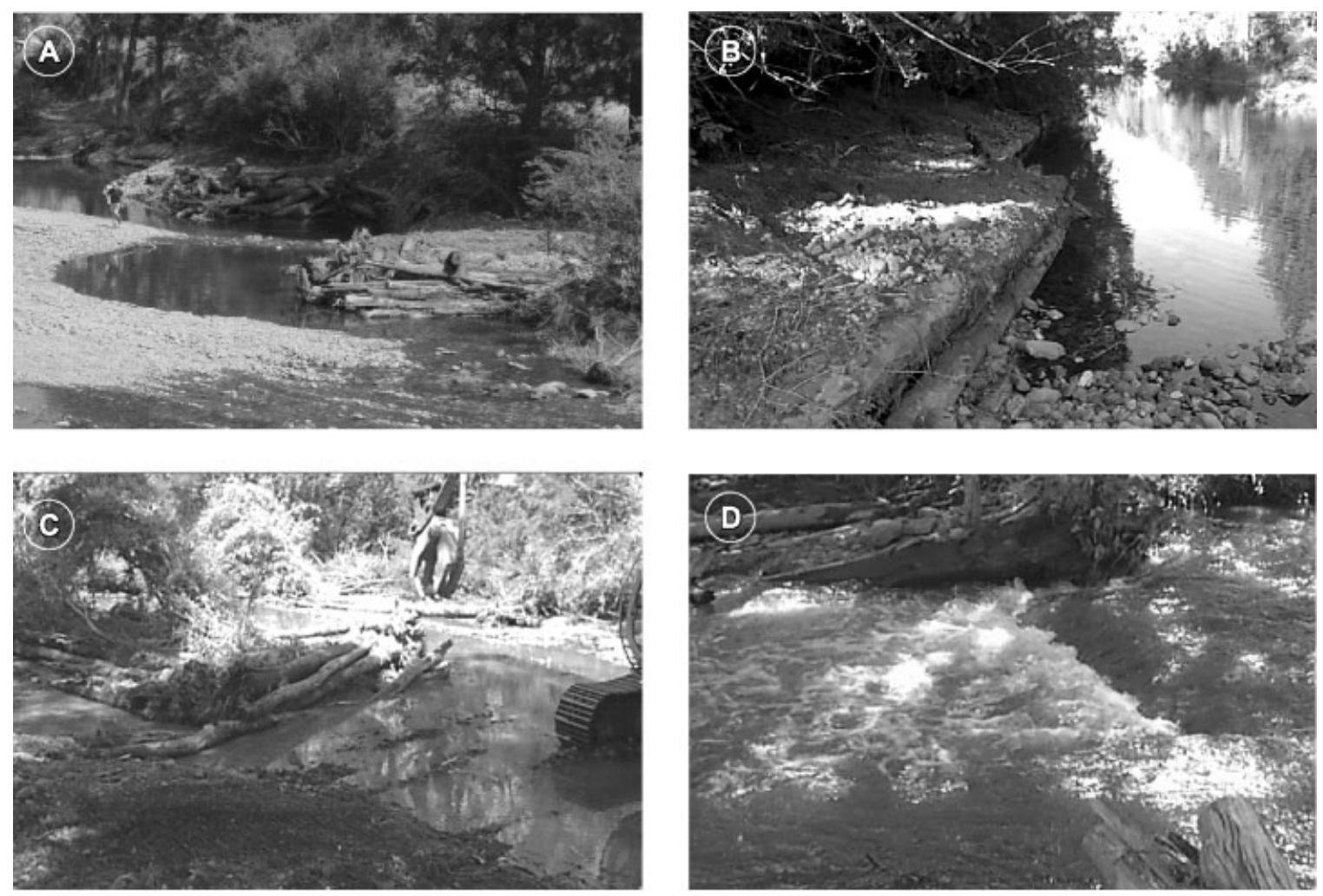

Figure 6. Examples of ELJs constructed in the test reach: (A) deflector jams; (B) bank revetment structure; (C) bar apex jam; (D) log sill bed control spanning between DFJ and BAJ 
Bar apex jams (BAJ1-2). These are mid-channel, multi-layered, impermeable log jams with ballast provided by gravel back-fill and additional ballast provided by any existing bar vegetation (Figure 6C). These log jams are built on or around existing mid-channel bars. ELJ dimensions depend on the size of the bar, or the desired endpoint feature. The functions of these structures are: (1) as direct mid-channel roughness elements; (2) mechanisms for stabilizing existing bars and inducing further bar accretion, thereby increasing form roughness; (3) habitat enhancement structures that increase the volume of wood in the channel and increase the diversity of in-stream habitats. The effect on form roughness (2) can be amplified when structures are located in association with existing riffles, as backwater effects can induce additional deposition and increase riffle crest height.

Log sill bed controls (LS1-5) and log sill complex (LSC1). These are triple log bed-control structures located perpendicular to flow and buried almost flush with the bed (raised above the bed by around one-third of the diameter of the upper log) (Figure 6D). The logs are placed one on two in a pyramid fashion. Ideally these structures are located in conjunction with DFJs or BAJs, such that the larger jam structures about either side of the log sill to minimize the possibility of outflanking and log sill removal. As a minimum, the log sills are set in place with longitudinal logs on either side of the channel. The functions of these structures include: (1) grade control; (2) reducing bed mobilization in small flows, particularly the transport of sediment into scour pools; (3) initiating of small scour pools; (4) increasing hyporheic zone exchange (A. Boulton, University of New England, personal communication, 2003).

\section{Assessment of morphological change}

To enable quantitative analysis of geomorphic change induced within the experimental reach, a detailed topographic survey of the test and control reaches was conducted with a total station theodolite (c. 1800-2000 survey points per channel km). The three-dimensional survey data were processed using Surfer 7 (a standard contouring and topographic modelling programme; Golden Software, 1999) to generate contours and quantify depth classes. The contouring process involved superimposing a $1 \times 1 \mathrm{~m} x-y$ grid, followed by application of a Radial Base smoothing function to fit an array of topographic contours across the channel zone at $0.25 \mathrm{~m}$ intervals in the $z$ dimension. Changes in the bed topography were quantified by comparing successive bed surveys with the baseline data measured prior to the ELJ construction in the test reach. The reach was resurveyed at an equivalent resolution after each bed mobilizing flow, in both the test and control reach. To date, two post-flood resurveys have been completed, after floods 2 and 3 (Figure 7). The short time between floods 1 and 2 prevented completion of the full resurvey during this interval; however, very little change was observed after this small flood.

\section{Bed material assessment}

Surface bed material texture was measured in all major hydrogeomorphic units (except the deepest pools) in the two study reaches according to Wolman's (1954) method. A total of 1800 clasts was measured in the test reach and 400 in the control reach at the commencement of the study and remeasured at the same locations following major bed mobilizing flows. These data were pooled to provide a reach-averaged measure of the bed-material characteristics to demonstrate changes between the reaches and to enable the assessment of bed mobility. Site-specific data were used for predicting bed scour depths as part of the ELJ design process. By comparing bed texture in rivers where WD had been removed with rivers that retained high WD loads, Buffington and Montgomery (1999) suggested that average bed texture should be finer in channels with high WD loadings and that there will be greater spatial variability in the distribution of material within a reach. They also suggested that spatial variability of bed material is an important constraint on fish populations within North American Rivers, primarily for the provision of appropriate spawning habitat.

\section{Fish community monitoring}

The control and test reaches were monitored at the same spatial and temporal resolution. Fish sampling was conducted by a boat-mounted electrofisher or a backpack electrofisher, where appropriate, depending on the habitat unit. Navigable habitat units were sampled using FRV Polevolt, a $3.6 \mathrm{~m}$ aluminium punt equipped with a $2.5 \mathrm{~kW}$ Smith-Root electrofishing system operated at between 340 and 1000 V DC, 3 to 15 A pulsed at $60 \mathrm{~Hz}$ and $70-90 \%$ duty cycle. Immobilized fish were dip-netted from the water to a live well, identified to species level, measured for length (fork length for species with forked tails, total length for species with rounded tails), and returned to the 

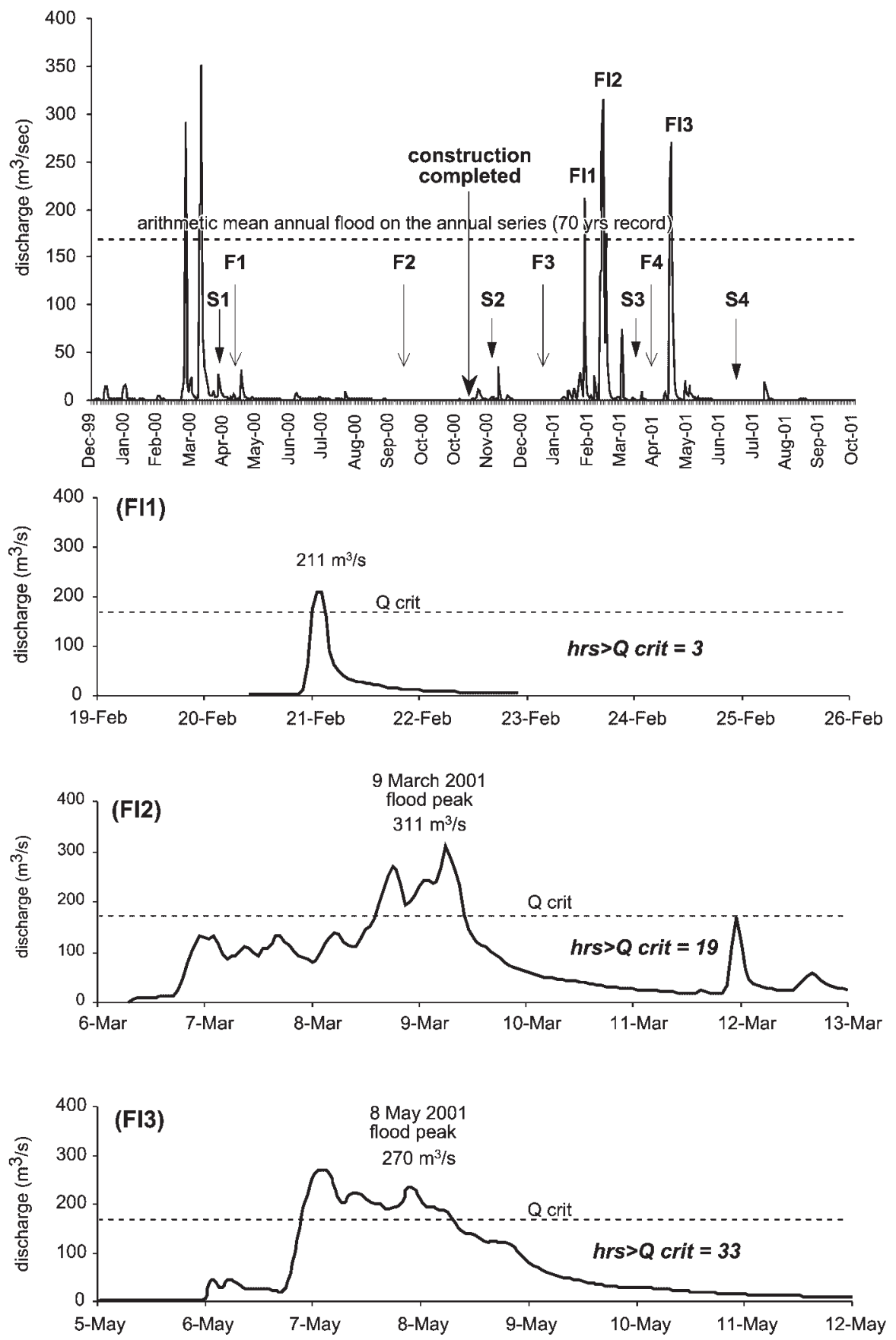

Figure 7. Flood hydrograph from Tillegra gauge (Stn 210011) $5 \mathrm{~km}$ downstream of the test reach from the commencement of reach monitoring. Experiment timeline is superimposed, showing the approximate dates of each bed survey (S1-4); fish survey (F1-4); and the three main postconstruction floods referred to in the text (FL1-3). The three lower graphs are enlargements of FL1-3 with the estimated reach-averaged critical threshold for bed entrainment superimposed on each plot. Shown on each graph is the number of hours flow exceeded the reach-averaged threshold for bed entrainment 
water alive. Fish observed to be affected by the electrofisher but not caught were also recorded where positive identification was possible. Each habitat unit was sampled by conducting a 2 min electrofisher shot within the designated habitat. Habitats too shallow to navigate were sampled in a similar manner using a $400 \mathrm{~W}$ Smith-Root Model 12 backpack electrofisher. A comprehensive suite of habitat attributes covering substratum type, particle size, structural habitat, riparian and aquatic vegetation, channel characteristics and cover was recorded for each habitat unit sampled.

The fish community was sampled twice per year, in spring and autumn, over two years, using a stratified sampling strategy based on equivalent effort per habitat unit. One spring and autumn sample was carried out before reintroducing woody habitat.

\section{RESULTS}

\section{Flood events since construction}

During the post-construction monitoring period the study site experienced five peak flows that over-topped most of the structures (Figure 7). Three of these peak flows exceeded the mean flood, inundating 18 of the ELJs by 2$3 \mathrm{~m}$. Based on the peak instantaneous discharge, the annual recurrence intervals on the annual series for floods 1-3 (Figure 7) respectively were around 2, 4 and 3 years. However, as indicated by the actual hydrographs for each of these events, coupled with the geomorphic data, peak instantaneous discharge is a poor predictor of the potential for each of these events to perform work on the channel. A better indication of the capacity for geomorphic work on the channel boundary is reflected by the duration of each event exceeding critical thresholds for bed material entrainment. In this case a reach-averaged estimate of critical entrainment threshold was determined for the test reach using the median particle size and the Ackers-White sediment transport equation (Ackers and White, 1973). From this analysis a different picture of the relative geomorphic effectiveness of the three events emerges as floods 1-3 exceed the threshold for 3, 19 and 33 hours, respectively (Figure 7). On this basis, flood 3 was potentially more geomorphically effective than flood 2, while the effectiveness of flood 1 was negligible. An understanding of the relative geomorphic effectiveness of each flood experienced during the experiment is important for interpreting the morphological response to each event.

\section{Morphological changes to the reaches}

The spatial distribution of net scour and deposition following the three bed mobilizing flows (i.e. residuals of change between survey 1 and 4) within the test reach is shown in Figure 8a with the corresponding changes to the control reach shown in Figure 8b. In the test reach most of the change took place following flood 2 (i.e. the first major flood post-treatment), and the effect of flood 3 was to accentuate the changes initiated by flood 2 . While a survey was not conducted immediately after flood 1 , field observation indicated that very little change was instigated by this event, confirming the analysis outlined above regarding the relative geomorphic effectiveness of the various floods. Clearly the extent of change is much more profound in the test reach than in the control, both in terms of the area of channel modified and the maximum depths of both scour and deposition. The difference in gross morphological response in the two reaches cannot be adequately explained by inter-reach variation. The changes to the test reach (Figure 8a) amount to a considerable increase in the complexity of the channel morphology, including increased amplitude of the riffle-pool sequence, and to a lesser extent the wavelength. These effects are most obvious in the upper half of the test reach, while the response to the lower half (i.e. below the large pool on the bend) is still notable but less ordered.

Figure 5 incorporates a prediction of the morphological effects following ELJ construction. Figure 8a demonstrates that these predictions represent a reasonably good approximation of the changes that transpired, although the observed response exceeded our predictions. Overall there has been profound change in channel morphology following the WD reintroduction, most of which is directly associated with the ELJ structures (cf. Figure 5). Deep scour pools have formed upstream of and adjacent to the two large deflector jams (DFJ1 and 2), while the riffle upstream of DFJ1 has aggraded, we assume as a result of the backwater effect created by the two deflector jams immediately downstream of the riffle. The riffle at DFJ3, LS1 and BAJ1 has also aggraded by as much as $0.5 \mathrm{~m}$, again associated with the direct effect of a log weir within the riffle plus the backwater effect created by the jams. 


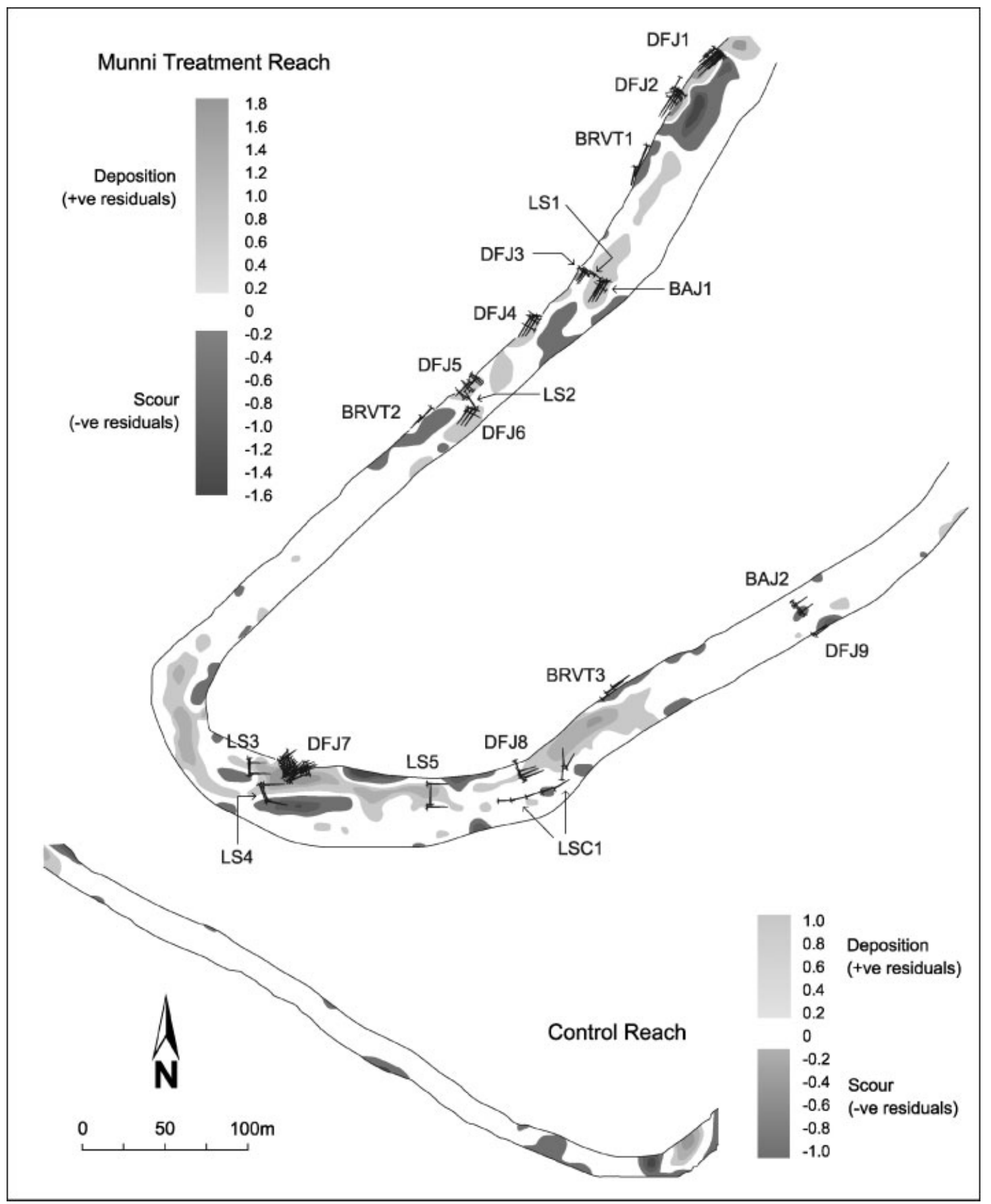

Figure 8. Contoured positive and negative residuals representing the net changes in bed topography following ELJ construction and the effect of three bed mobilizing flows. ELJ locations are shown to highlight the relationship between channel adjustments and structure locations. Compare observed changes with predicted changes shown in Figure 5 
We hypothesize that the aggradation of this riffle is accentuated by the additional local sediment supply mobilized from the scour pools at DFJ1 and 2, although the fact the test reach has experienced net aggradation suggests there has also been significant sediment input from upstream. Immediately downstream of DFJ3 and BAJ1 channel scour has been initiated through a combination of channel contraction and increased deflection of flows into the bedrock located on the left bank immediately downstream of BAJ1. The combined effect of the riffle aggradation and scour downstream has been to substantially steepen the riffle, as well as to raise the backwater pool level behind the riffle. The series of structures in the straight reach downstream of BAJ1 (DFJ4, 5 and 6; LS2 and BRVT2) have contracted the low flow channel from its former (over-widened) state, initiated a new riffle between DFJ5 and 6, where none previously existed, and accentuated the scour downstream of the riffle. As outlined above, the combined effect of all these changes has been to increase pool-riffle amplitude by raising average riffle height by $0.3-$ $0.5 \mathrm{~m}$, and deepen pools, both as a result of increased riffle crest height and bed scour. Riffle-pool wavelength decreased through the addition of a new riffle in the vicinity of DFJ6 (Figures $2 b$ and 5).

Figure 9 provides a more quantitative assessment of the morphological changes that have occurred in both reaches since WD reintroduction. The histograms quantify volumetrically the changes shown spatially in Figure 8 , thereby enabling the determination of the degree of scour and deposition in $0.2 \mathrm{~m}$ depth slices. This analysis also allows us to determine the net change to sediment storage within each reach following each flood. The additional
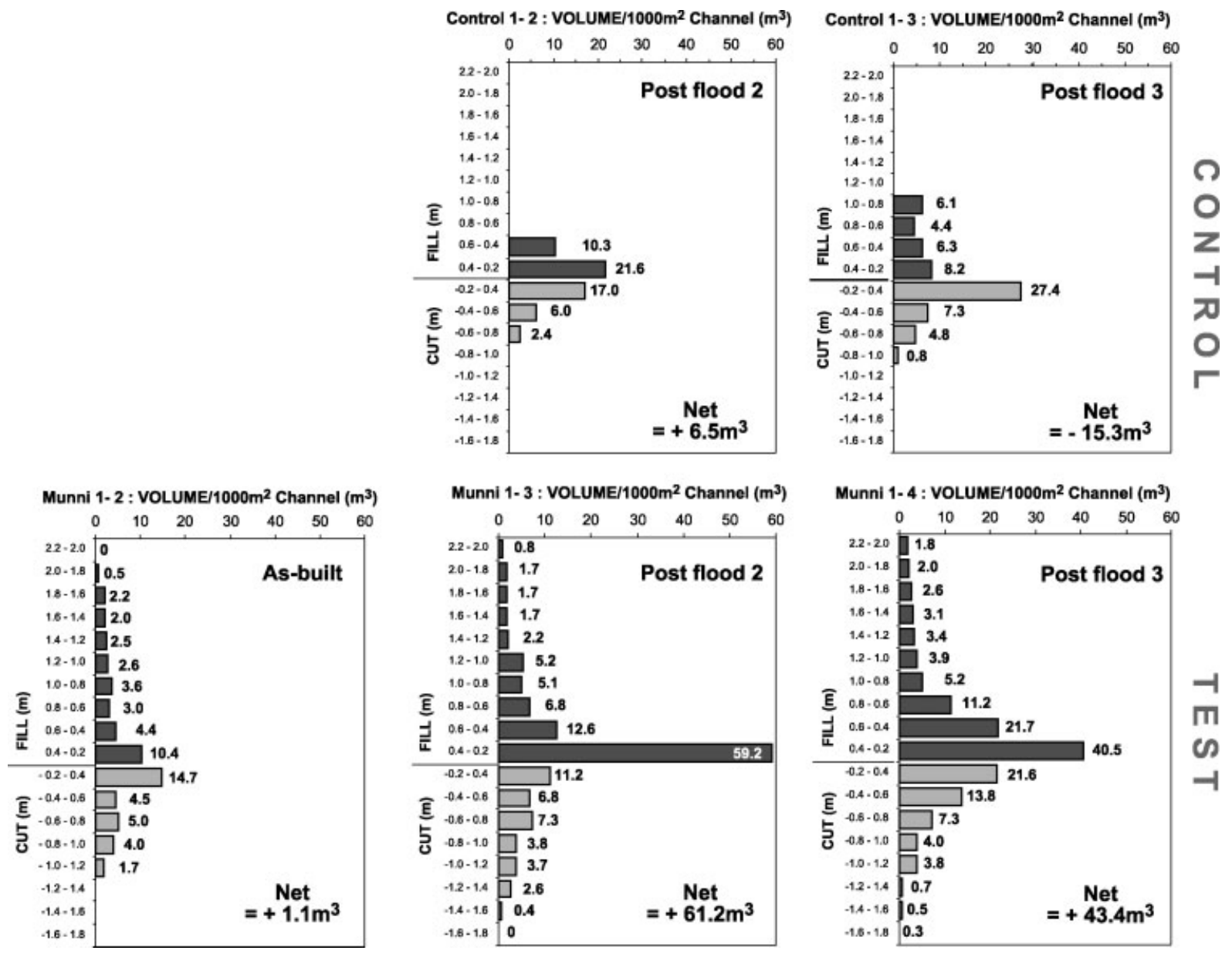

Figure 9. Graphs showing residuals of change for surveys 2, 3 and 4 in the test reach and 2 and 3 in the control (i.e. the timing of control surveys 2 and 3 = surveys 3 and 4 from the test reach) with respect to the baseline survey 1 broken into $0.2 \mathrm{~m}$ depth classes. Each class represents the volume of sediment deposited or scoured above or below the initial ground surface in the $0.2 \mathrm{~m}$ class indicated. The data are area normalized per $1000 \mathrm{~m}^{2}$ of bed surface area. Data in the range $-0.2 \mathrm{~m}$ to $+0.2 \mathrm{~m}$ have been excluded from all plots as they are assumed to predominantly represent measurement and smoothing error 
survey in the test reach serves to quantify the changes imposed by the rehabilitation strategy, which was obviously not required for the control.

Following flood 2 the net accretion per unit area of bed within the test reach was almost an order of magnitude greater than the control. Furthermore, maximum accretion depths (compared with the baseline surface elevation) in the control were $0.6 \mathrm{~m}$, while in the test reach they were up to $2.2 \mathrm{~m}$. Similarly maximum scour depths of $0.8 \mathrm{~m}$ were achieved in the control reach while they were up to $1.6 \mathrm{~m}$ in the test reach. The area-normalized data shown in Figure 8 equate to $2100 \mathrm{~m}^{3}$ of sediment deposited by flood 2 within the $1100 \mathrm{~m}$ long test reach. Given that the asbuilt survey data relate directly to built $\log$ jams, it is apparent that the maximum depth of deposition is controlled by the elevation of the structures. Considering the spatial distribution of scour and deposition in the test reach, it is clear that there is a direct relationship between the observed morphological adjustments within the reach and the ELJs (Figure 8).

The net effect of the third flood on both reaches provides an interesting contrast, both between the reaches and compared with the previous flood. In both reaches a net loss of sediment occurred. However, due to the substantial volumes of sediment deposited by flood 2 in the test reach, there remained a net gain of sediment to the reach compared with the baseline condition, whereas a net loss is evident within the control. In the control most of the net scour was sourced from sections of the channel that were scoured by the previous flood, but primarily from the $-0.2-0.4 \mathrm{~m}$ depth class. On the accretion side there is an overall loss of accreted sediment between floods 2 and 3 , but there is some evidence that sediment was reworked from lower to higher elevations in the channel: losses in classes up to $+0.6 \mathrm{~m}$ are partly offset by gains in classes $+0.6-1.0 \mathrm{~m}$. In the test reach a similar pattern is evident, with the majority of sediment losses coming from the relatively shallow depth classes $(+0.2-0.4 \mathrm{~m}$ and $-0.2-$ $0.6 \mathrm{~m}$ ). The key difference here compared with the test reach is that while net scour occurred, there was also a substantial redistribution of accreted sediment to higher elevations (i.e. all classes $>+0.4 \mathrm{~m}$ ). Thus the effect of flood 3 on the test reach was to accentuate all the changes initiated by flood 2, with the exception of the sediment accreted in the depth class $+0.2-0.4 \mathrm{~m}$. This would be the most readily accessible material on the surface of the main bed. In summary, the pools and scour zones were deepened, and the bars and depositional areas were built up. The net effect of this has been that there have been increases in both the riffle and pool area, at the expense of the units previously classified as glide (Figure 2).

From the volumetric data shown in Figure 9, we conclude that flood 2 was a 'depositional flood' and flood 3 was an 'erosional flood'. The evidence regarding the geomorphic effectiveness of the various events supports this assertion. The depositional characteristics of the two floods were probably also influenced by the decay rates of the receding limbs of the two flood hydrographs. Figure 7 shows that discharge fell rapidly in flood 2 and more slowly in flood 3.

\section{Bed texture changes}

The reach-averaged bed-material frequency distribution shown in Figure 10 provides further evidence for significant geomorphic changes associated with WD reintroduction. In the test reach there was a statistically significant fining of bed material following flood $2(t$-test $P<0.1)$. However, following the third flood this difference had disappeared $(P>0.5)$, with the frequency distribution returning to a condition similar to the baseline. In the control, only one post-flood survey was available for comparison, after the third flood, but this shows significant coarsening in the bed material $(P<0.01)$. There was no significant difference between the baseline condition of the two reaches $(P>0.5)$, but following flood 3, reach-averaged bed-material size in the control was significantly coarser than that in the test reach $(P<0.005)$. Notwithstanding the lack of a bed material resurvey after the second flood in the control reach, it is reasonable to assume that without the effect of the WD in the test reach the reach-averaged particle size would have been much coarser than observed.

In addition to the evidence that WD reintroduction has led to significant fining of bed material at the reach scale, the site-specific data support the link between the log structures and increased variability in the spatial distribution of sediments. Figure 11 shows the percentage deviation from the baseline of the d35, d50 and d84 particle sizes for geomorphic units resurveyed after each flood. Not surprisingly, the majority of units are substantially finer than the baseline condition, with the notable exception of the last four or five units, which are generally coarser. These have been interpreted as evidence of local sediment starvation of the finer fraction transported by flood 2, much of which 


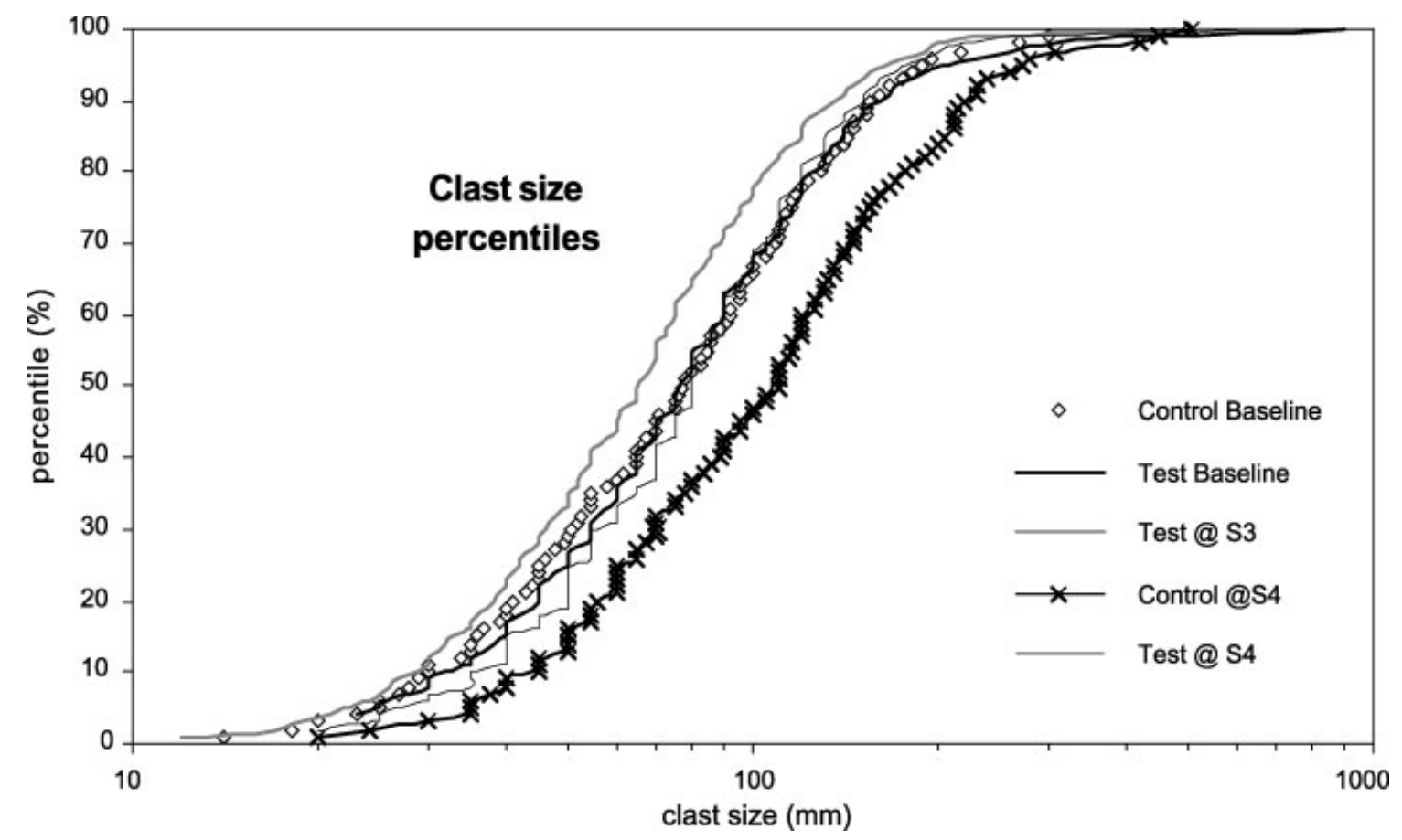

Figure 10. Reach-averaged bed-material frequency distribution plots for control and test reach for surveys conducted at the times indicated on Figure 7

was deposited in the upper three-quarters of the reach in the vicinity of the log structures. The single coarser unit at G4.71 is at a site where the channel thalweg has shifted due to the channel realignment initiated by DFJ7. A substantially different picture emerges after flood 3, demonstrating that the overall coarsening evident from the reachaveraged data (back to something similar to the baseline) is by no means spatially consistent. Much of the finer material deposited by flood 2 still remains, almost exclusively in association with log structures, whereas there has been substantial coarsening in units within the channel that were not offered protection from ELJs. The net effect of these three floods in association with the log structures is that variability in the spatial distribution of bed material has increased markedly. This trend is not evident in the reach-averaged data, but could be critical to the ecological functioning within the reach.

\section{Fish community response}

A total of 2885 fish was recorded over the four sampling occasions, representing 13 species (Table III). Eight species were recorded from the control reach, for a total of 545 fish, whilst twelve species were caught from the test reach for a total of 2340 fish. The most common species in both reaches were Australian smelt (Retropinna semoni), Cox's gudgeons (Gobiomorphus coxii) and long-finned eels (Anguilla reinhardtii).

The mean number of fish species per electrofishing shot in the control reach increased by $30.2 \%$, from $2.4 \pm 0.2$ before rehabilitation to $3.1 \pm 0.2$ after rehabilitation $(P<0.05)$ (Figure 12). In the test reach, the mean number of fish species per electrofishing shot after rehabilitation $(3.1 \pm 0.1)$ was $50.4 \%$ greater than before rehabilitation $(2.1 \pm 0.1)(P<0.0001)$. The mean abundance of fish per shot in the control reach decreased slightly from $13.2 \pm 5.2$ before rehabilitation, to $11.6 \pm 1.5(P>0.05)$, although there was a significant interaction between the time of sampling before and after rehabilitation (Figure 13). In contrast, the test reach showed a $53.4 \%$ increase in mean fish abundance after rehabilitation, increasing from 13.2 \pm 2.1 fish per electrofishing shot before the addition of structural woody habitat to $20.3 \pm 2.1$ afterwards $(P<0.001)$.

Multi-dimensional scaling ordination of fish assemblages in control and test reaches on each sampling occasion shows different trajectories over time for each reach (Figure 14). Before addition of woody habitat to the test reach, 


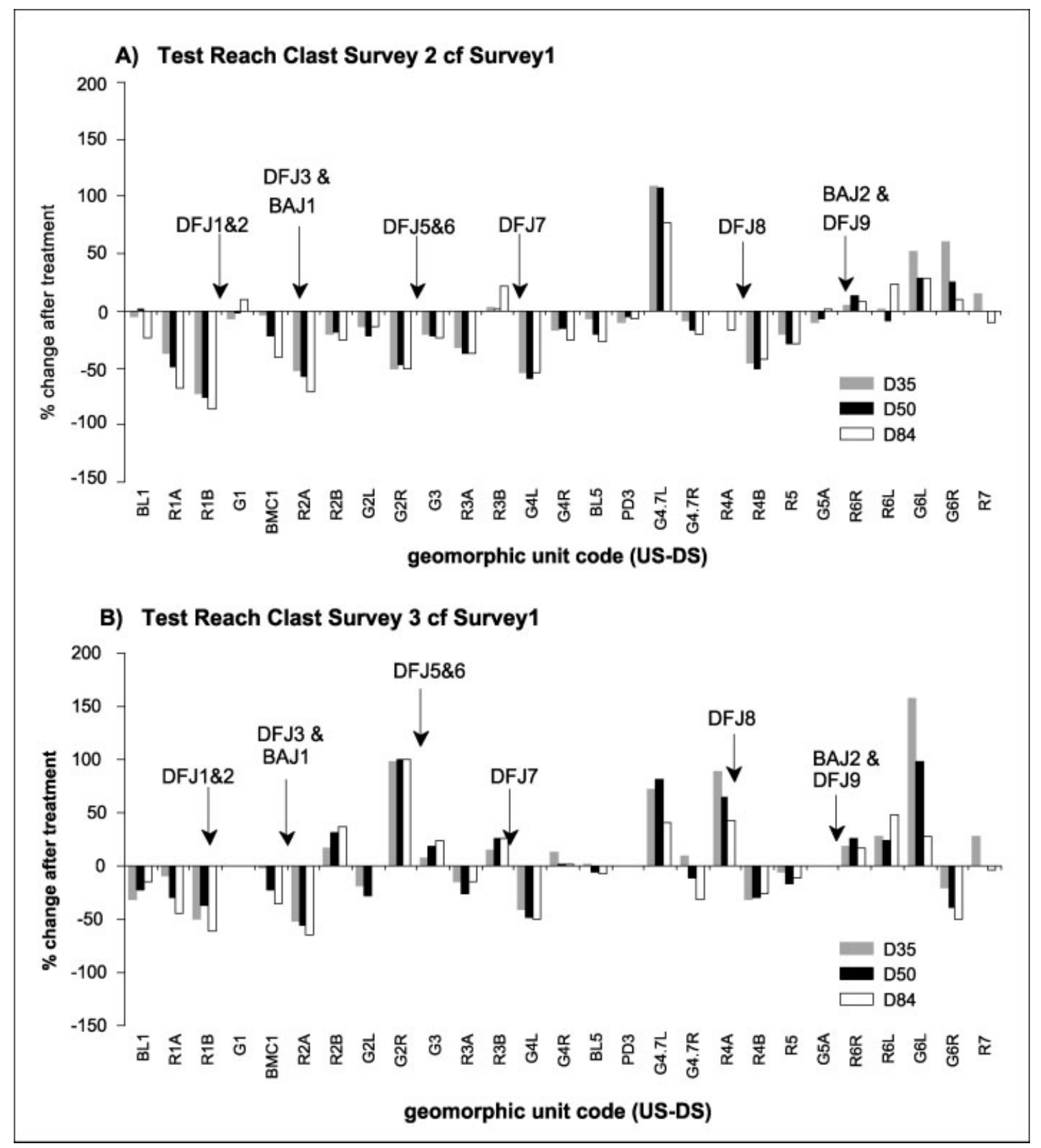

Figure 11. Percentage variation with respect to the baseline condition in $\mathrm{d} 35, \mathrm{~d} 50$ and $\mathrm{d} 84$ measures at each sample location down the test reach after floods 2 and 3. Approximate locations of prominent ELJs as indicated on Figure 5 are shown on the graph to help locate the sample points down the reach

both assemblages occupied similar loci, displayed similar variability between samples, and moved in the same direction between samples (Analysis of Similarity $P>0.5$ ). In contrast, the control reach maintained its variability between samples after rehabilitation, but the fish assemblage in the test reach displayed reduced variability and a different trajectory to the control reach, creating a significant difference between the two assemblages (Analysis of Similarity $P<0.01$ ). Changes in the fish assemblage in the control reach were significant after the addition of structural woody habitat to the test reach $(P<0.05)$, but were less marked than the changes that occurred over the same period in the test reach $(P<0.001)$. 
Table III. Summary of fish catches from control and test reaches of the Williams River

\begin{tabular}{|c|c|c|c|c|c|c|c|c|c|c|c|}
\hline \multirow{2}{*}{$\begin{array}{l}\text { Species } \\
\text { Sample time }\end{array}$} & \multirow[b]{2}{*}{1} & \multicolumn{2}{|c|}{ Control } & \multirow[b]{2}{*}{4} & \multirow[t]{2}{*}{ Total } & \multicolumn{4}{|c|}{ Test } & \multirow[t]{2}{*}{ Total } & \multirow[t]{2}{*}{ Grand total } \\
\hline & & 2 & 3 & & & 1 & 2 & 3 & 4 & & \\
\hline No. samples & 11 & 11 & 11 & 11 & 44 & 30 & 23 & 37 & 36 & 133 & 177 \\
\hline Anguilla australis & 0 & 0 & 0 & 0 & 0 & 0 & 1 & 0 & 0 & 1 & 1 \\
\hline Anguilla reinhardtii & 40 & 22 & 25 & 27 & 114 & 86 & 68 & 91 & 86 & 331 & 445 \\
\hline Gambusia holbrooki & 0 & 0 & 0 & 0 & 0 & 0 & 0 & 0 & 1 & 1 & 1 \\
\hline Gobiomorphus australis & 0 & 0 & 0 & 1 & 1 & 0 & 0 & 0 & 0 & 0 & 1 \\
\hline Gobiomorphus coxii & 23 & 16 & 35 & 34 & 108 & 28 & 41 & 217 & 152 & 438 & 546 \\
\hline Macquaria novemaculeata & 8 & 3 & 19 & 45 & 75 & 8 & 3 & 31 & 32 & 74 & 149 \\
\hline Mugil cephalus & 0 & 0 & 7 & 0 & 7 & 0 & 2 & 1 & 6 & 9 & 16 \\
\hline Myxus petardi & 0 & 0 & 0 & 0 & 0 & 1 & 0 & 0 & 1 & 2 & 2 \\
\hline Philypnodon grandiceps & 0 & 0 & 0 & 0 & 0 & 0 & 0 & 2 & 0 & 2 & 2 \\
\hline Philypnodon sp. 1 & 0 & 0 & 1 & 0 & 1 & 0 & 0 & 3 & 4 & 7 & 8 \\
\hline Potamalosa richmondia & 0 & 0 & 0 & 0 & 0 & 0 & 0 & 0 & 1 & 1 & 1 \\
\hline Retropinna semoni & 145 & 28 & 18 & 37 & 228 & 396 & 80 & 431 & 521 & 1428 & 1656 \\
\hline Tandanus tandanus & 4 & 1 & 1 & 5 & 11 & 12 & 6 & 5 & 23 & 46 & 57 \\
\hline Grand Total & 220 & 70 & 106 & 149 & 545 & 531 & 201 & 781 & 827 & 2340 & 2885 \\
\hline
\end{tabular}

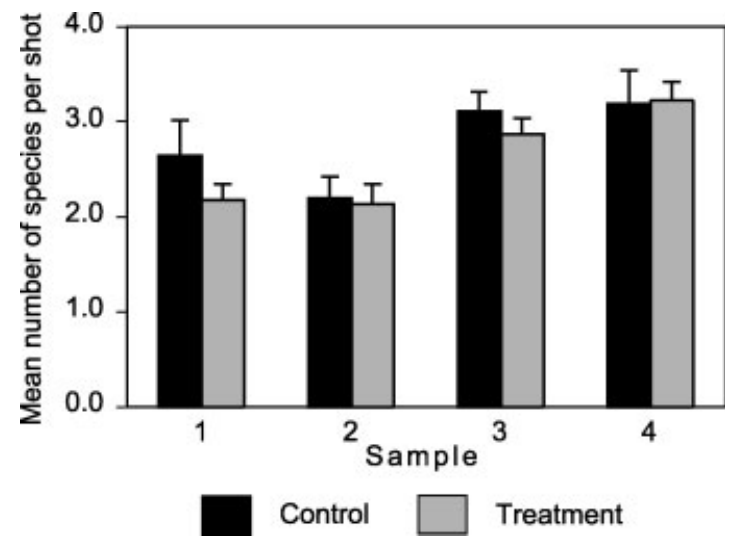

Figure 12. Changes in species richness, estimated as the mean number of fish species per electrofishing shot, before (samples 1 and 2) and after (samples 3 and 4) placing structural woody habitat in the test reach of the Williams River

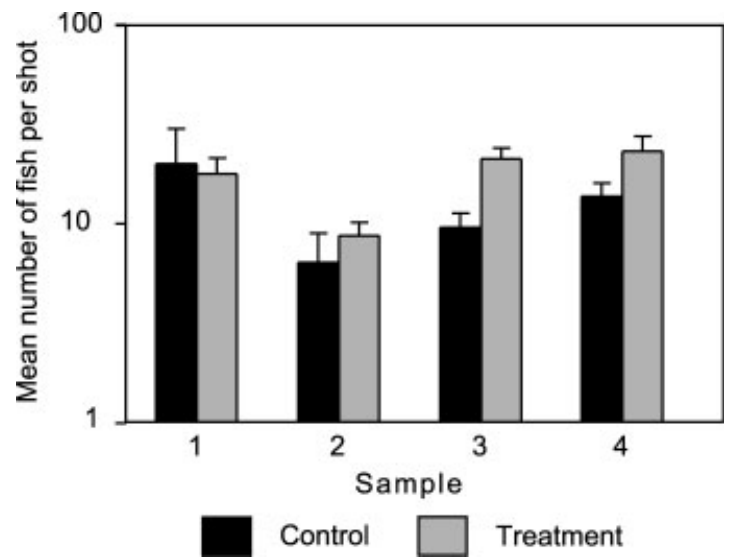

Figure 13. Changes in fish abundance, estimated as the mean number of individuals per electrofishing shot, before (samples 1 and 2 ) and after (samples 3 and 4) placing structural woody habitat in the test reach of the Williams River 


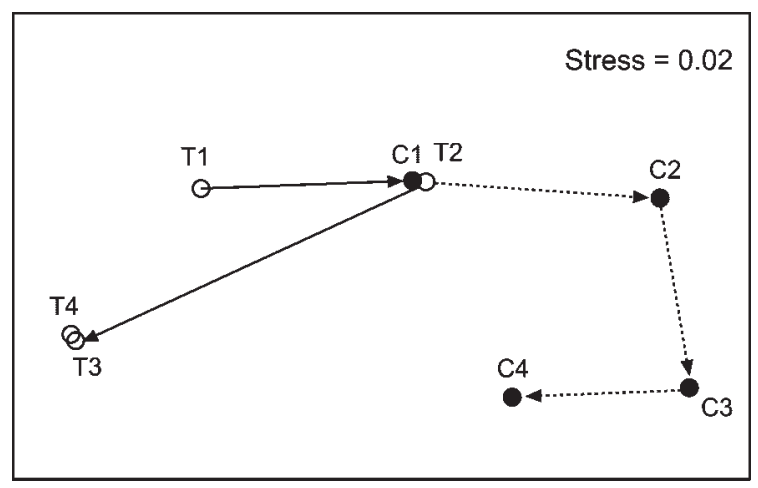

Figure 14. Multi-dimensional scaling ordination showing trajectories and variability of fish assemblages in the control reach (solid symbols) and test reach (hollow symbols) before (samples 1 and 2) and after (samples 3 and 4) placing log structures in the test reach

Before the rehabilitation works were undertaken, fish assemblages in the control and test reaches had a dissimilarity of $70.5 \%$. This difference is reflected in the greater abundance of Australian smelt and long-finned eels, and the lower abundance of Cox's gudgeons and Australian bass in the test reach compared to the control reach (Table IV). After the addition of structural woody habitat, Australian smelt and Cox's gudgeons became even more abundant in the test reach compared to the control reach. Australian bass increased in abundance in both reaches, although the increase was greater in the control reach.

The main changes in the fish assemblage in the control reach over time were the reduced abundance of Australian smelt and long-finned eels, and the increased abundance of Australian bass and Cox's gudgeons. Over the same interval, the test reach showed an increase in the abundance of Australian smelt, Cox's gudgeons and Australian bass, with a small decline in numbers of long-finned eels.

Table IV. Summary of similarity percentages analysis to identify species contributing to differences between control and test reaches before and after rehabilitation of the test reach

\begin{tabular}{|c|c|c|c|}
\hline Species & Mean abundance & Mean abundance & $\%$ Contribution \\
\hline Before rehabilitation & $\begin{array}{l}\text { Control } \\
\text { Dissimilarity }=70.5 \%\end{array}$ & Test & \\
\hline Retropinna semoni & 7.86 & 8.98 & 47.8 \\
\hline Anguilla reinhardtii & 2.82 & 2.91 & 25.3 \\
\hline Gobiomorphus coxii & 1.77 & 1.30 & 16.1 \\
\hline Macquaria novemaculeata & 0.5 & 0.21 & 5.50 \\
\hline After rehabilitation & $\begin{array}{l}\text { Control } \\
\text { Dissimilarity }=67.4 \%\end{array}$ & Test & \\
\hline Retropinna semoni & 2.50 & 13.04 & 41.7 \\
\hline Gobiomorphus coxii & 3.14 & 5.05 & 22.8 \\
\hline Macquaria novemaculeata & 2.91 & 0.86 & 16.2 \\
\hline Anguilla reinhardtii & 2.36 & 2.42 & 12.8 \\
\hline Control reach & $\begin{array}{l}\text { Before } \\
\text { Dissimilarity }=66.4 \%\end{array}$ & After & \\
\hline Retropinna semoni & 7.86 & 2.50 & 29.9 \\
\hline Macquaria novemaculeata & 0.50 & 2.91 & 22.8 \\
\hline Gobiomorphus coxii & 1.77 & 3.14 & 22.1 \\
\hline Anguilla reinhardtii & 2.82 & 2.36 & 19.0 \\
\hline Test reach & $\begin{array}{l}\text { Before } \\
\text { Dissimilarity }=70.1 \%\end{array}$ & After & \\
\hline Retropinna semoni & 8.98 & 13.04 & 50.2 \\
\hline Gobiomorphus coxii & 1.30 & 5.05 & 23.1 \\
\hline Anguilla reinhardtii & 2.91 & 2.42 & 16.2 \\
\hline Macquaria novemaculeata & 0.21 & 0.86 & 5.00 \\
\hline
\end{tabular}




\section{DISCUSSION}

\section{Geomorphic response}

Somewhat fortuitously, the first 12 months in the post-treatment phase of this experiment have provided ideal conditions for rigorously evaluating the effectiveness of the rehabilitation strategy from an engineering and geomorphic perspective, as well as establishing the right conditions to trigger an ecological response. The engineering aspects of the strategy have not been the focus of this paper, but it is fair to say the structures have performed extremely well under trying conditions. From a geomorphic perspective, the observed response has far exceeded expectations. Eroding banks have been stabilized, substantial volumes of gravel have been trapped within the reach, riffles have been raised by as much as $0.5 \mathrm{~m}$, and a complete new sequence of meso-habitat scale geomorphic units has been created. Excess transport and supply of sediment resulting from historical channel enlargement and reduced hydraulic roughness within channels is probably one of the greatest management problems in coastal rivers in southeastern Australia (Brooks and Brierley, in press). Thus, this experiment demonstrates a technique that can begin to transform channels similar to this one from high-energy throughput zones to reaches that store sediment over the medium term. This is not to say that sediment will continue to be trapped at the same rate as occurred in flood 2. Indeed the response associated with flood 3 indicates the sediment trapping capacity of the reach may have already been reached. Yet, even so, the response to flood 3 also provides evidence that a compounding response may continue, which might further increase the morphological variability of the reach, and hence it is assumed improve habitat quality (Frothingham et al., 2001).

Morphological variability has increased markedly after floods 2 and 3. Prior to the treatment the test reach was dominated by morphologically homogeneous plane-bed sections of channel (Montgomery and Buffington, 1997) where the low flow water depth rarely exceeded $0.5 \mathrm{~m}$. The only deep water was associated with the large bedrock bend. Now there are greater areas of deep water (i.e. $>1.0 \mathrm{~m}$ ) in the former plane-bed sections of channel. Similarly there is a greater diversity of hydraulic conditions at low flow. Both riffle and pool areas have increased, and the riffles tend to be longer and higher. The bed material results also indicate there has been increased diversity of bed material sediments that may imply an improvement in the quality of the micro-habitat within the reach. The fining trend observed with flood 2 and the increased complexity evident after flood 3, are consistent with the data presented by Buffington and Montgomery (1999) who highlighted the relationship between WD and bed texture. However, the intra-reach variability observed, particularly after flood 3, highlights the need to look at responses across a range of spatial scales. Reach-averaged trends alone would have obscured some significant intra-reach changes in the test reach channel morphology.

\section{Fish response}

The results of fish sampling in this study are similar to those of Gehrke and Harris (2001) for the Williams River further downstream near the town of Dungog. In addition to the species recorded here, the earlier study recorded empire gudgeons (Hypseleotris compressa) and bullrouts (Notesthes robusta), but failed to collect short-finned eels and gambusia (Gambusia holbrooki) between 1994 and 2000.

The increased abundance of species such as Australian smelt and Cox's gudgeon in the test reach appears to be associated with the increased habitat complexity induced by the rehabilitation strategy. The trajectories of fish assemblages in both control and test reaches differed, with the assemblage in the test reach becoming more stable after the addition of woody habitat. This result suggests that the addition of structural woody habitat to the test reach, and the resultant geomorphic changes in channel form and sediment retention, have had short-term benefits for the local fish community.

These results are consistent with those of Roni and Quinn (2001) in salmonid streams of the Pacific Northwest, who found that juvenile coho salmon (Oncorhynchus kisutch) densities were higher in reaches with increased woody habitat than in reference reaches, and that coho density was correlated with the magnitude of changes in physical habitat. Densities of juvenile cutthroat trout (Oncorhynchus clarki) and steelhead trout (Oncorhynchus mykiss) were higher in treatment reaches in winter only.

When assessing the success of fish habitat creation works, it can be difficult to distinguish between long-term changes in fish production in the rehabilitated area, and increased attraction of fish from nearby habitats into the 
modified area (e.g. Riley and Fausch, 1995). Movement of fish among reaches in the Williams River is likely, considering the migratory behaviour of most of the species recorded (Gehrke et al., 2002). This possibility is enhanced by the observations of Kahler (1999) that juvenile coho salmon in poor-quality habitat were more likely to move than those in better-quality habitat.

The design of this study does not enable the cause of the observed changes in fish assemblages to be identified with certainty, and the study duration is as yet too short to detect increased fish numbers in the test reach that might reflect real changes in fish production. However, it is considered that the increased numbers of small fish, like Australian smelt and Cox's gudgeon, are most likely to reflect increased retention of these species in the test reach during high flow events. The increased retention of sediment over the same period confirms a net reduction in the flow velocity within the channel of the test reach. Cox's gudgeons are predominantly a benthic species, and may find both an increase in habitat availability and reduced displacement by high flows in the test reach. In contrast, Australian smelt are a pelagic species often encountered in pools or riffle habitats that carry most of the high flows in this section of the Williams River. This species would also be expected to experience strong downstream displacement during high flows in the Williams River, and so might increase in the test reach as fish carried from upstream find refuges from high flows in the lee of structural woody habitats created in this study.

It is also possible that the high flow events may have stimulated upstream migration of species such as Australian smelt and Cox's gudgeon during the rising and falling limbs of the hydrograph either side of the flood peak (Gehrke et al., 2002). Fish migrating upstream would also find refuges from high flows in the test reach.

Reeves et al. (1991) suggested that monitoring for two generations might be needed to detect population responses to habitat improvement at the stream scale. For habitat restoration to be effective at an ecologically significant level, Reeves et al. (1991) suggested that monitoring is required at the catchment scale rather than at the reach scale. Most habitat restoration works in the Pacific Northwest occur at a scale of 100-500 m (Roni and Quinn, 2001), and even the test reach in the Williams River was only $1100 \mathrm{~m}$ long, so that monitoring at catchment scale is unlikely to detect changes in fish communities unless the rehabilitation works are conducted over a commensurate spatial scale.

This study has shown that creating additional habitat complexity by reintroducing structural woody habitat to rivers may improve conditions for some species of fish. Longer-term studies are required on a large scale to confirm whether these changes are permanent or transient, and the spatial scale required for rehabilitation projects to restore fish production and species diversity to the levels that existed before the occurrence of large-scale habitat degradation.

\section{CONCLUSION}

There is an increasing body of literature that has documented dramatic geomorphic changes to alluvial rivers as a result of anthropogenic disturbance to channels and riparian zones and to catchments, particularly in New World countries, where the changes are more recent and tend to be more pronounced (Knox, 1977; Brooks et al., in press). Almost invariably, changes associated with human disturbance to channels and catchments have led to gross homogenization of channel morphology at the macro-, meso- and micro-habitat scales (Beechie et al., 2001; McDowell, 2001; Brooks et al., in press). It has been hypothesized that these geomorphic changes alone have had a devastating effect on aquatic ecosystems. In broad terms, the Williams River, where this study was conducted, is no different to many rivers in eastern Australia, having experienced extensive channel change in the period following riparian vegetation clearance, and particularly in the last few decades following the desnagging programme (Brooks et al., 2001). This experiment has demonstrated that even in the face of these gross geomorphic changes, the rehabilitation of channel geomorphology is possible over very short timeframes. It has also confirmed the significance of WD as a direct control on channel morphology in mobile gravel-bed rivers. This is not to say the study reach is now 'rehabilitated'. Rather, it has been demonstrated that at a level of intervention commensurate with some of the historical disturbances, a significant 'kick start' can be given to the rehabilitation process. Over the longer term there is no substitute for sound riparian management that incorporates the exclusion of stock from river channels

and adjacent riparian land and the promotion of substantial belts of native riparian forest to act as a future natural source of WD. Future management will also need to accommodate a certain degree of lateral instability if rivers are to regain some of their original characteristics. 
This study also has implications for fish monitoring programmes and for rehabilitation projects that specifically target the rehabilitation of fish habitat. The critical habitat for many native fish species is often assumed to be at the micro-habitat scale, such as the habitat associated with bed material clasts, bank undercuts and conditions around individual logs. Meso-habitat scale features, such as pool-riffle sequences, are often thought to be relatively fixed features in the landscape that are independent variables for the purpose of designing a fish monitoring or rehabilitation strategy. Fish monitoring strategies within dynamic river styles (cf. Brierley et al., 2002) need to be sufficiently flexible to accommodate major 'habitat' changes during the life of a programme. Similarly there are implications for the design of rehabilitation strategies targeted at the requirements of individual species or suites of species. While it may be possible to design a rehabilitation strategy that independently targets certain microhabitat scale conditions (for example, a bank overhang or a single log) there may well be higher order controls that will negate attempts to address these issues, if they are not addressed simultaneously, at least (Sear, 1994). A good example might be high sediment flux through a reach, which could bury individual logs or cause the erosion of undercut banks as the channel expands to accommodate the sediment load. A rehabilitation programme aimed at reducing sediment flux by necessity must be focused at broader scales, be they reach or catchment scale. Often it will not be possible to design a rehabilitation strategy that directly targets improvements at the micro-habitat scale. If, for example, the rehabilitation goal is to improve habitat associated with bed substrate composition and diversity, the rehabilitation strategy will need to be implemented at a broader meso-habitat, reach or catchment scale. Such strategies will need to be aware of complex, non-linear responses to the broader scale treatments. The results from this study have hinted at some of the complex responses to a treatment employed within a single river reach. Predicting the longer-term character of responses to treatments at reach or catchment scale rehabilitation programmes represents a challenge for future research.

\section{ACKNOWLEDGEMENTS}

The research component of this project is funded through LWA Grant MQU9 and GRU29 while the works component is funded by NSW Department of Land and Water Conservation, Hunter Region and Hunter Catchment Management Trust. We thank Chris Muddle, Laurie Rumbel, Dave Rumbel and Stuart Garrard from the Williams River work crew; Matt Taylor, Rod Gleeson, Stuart Johnson, Greg Jones, David Outhet, Estelle Avery, James Lander, Suzanne Kinsley, Simon Hartley, Andrew Bruce, Tom Rayner, Michael Rodgers and Ian Wooden for assistance with field sampling, survey work, and data processing. We also thank Chris Gippel for input into the study design. We gratefully acknowledge Mr Edwin and Mrs Naida Smith of 'Munni' for allowing access to their land and for their support of this project. Thanks also to Dean Oliver for drafting figures.

\section{REFERENCES}

Abbe TB. 1999. Engineered log jam habitat enhancement report—site conditions, geomorphic analysis, project objectives and design proposal. Skagit County, Lummi Indian Nation, Deptartment of Natural Resources.

Abbe TB. 2000. Patterns, mechanics and geomorphic effects of wood debris accumulations in a forest river system. PhD dissertation, University of Washington, Seattle, WA.

Abbe TB, Montgomery DR. 1996. Large woody debris jams, channel hydraulics, and habitat formation in large rivers. Regulated Rivers: Research and Management 12: 201-221.

Abbe TB, Montgomery DR, Petroff C. 1997. Design of stable in-stream wood debris structures for bank protection and habitat restoration: an example from the Cowlitz River, WA. In Proceedings of the Conference on Management of Landscapes Disturbed by Channel Incision, Wang SSY, Langendoen EJ, Shields FD Jr (eds). University of Mississippi: 809-816.

Ackers P, White WR. 1973. Sediment transport—new approach and analysis. Journal of the Hydraulics Division ASCE 99(HY11): 2041-2060.

Beechie TJ, Collins BD, Pess GR. 2001. Holocene and recent geomorphic processes, land use, and salmonid habitat. In Geomorphic Processes and Riverine Habitat, Dorava JM, Montgomery DR, Palcsak BB, Fitzpatrick FA (eds). American Geophysical Union: Washington, DC; 3756.

Bosch JM, Hewlett JD. 1982. A review of catchment experiments to determine the effect of vegetation changes on water yield and evapotranspiration. Journal of Hydrology 55: 3-23.

Brierley G, Fryirs K, Outhet D, Massey C. 2002. Application of river styles framework as a basis for river management in New South Wales, Australia. Applied Geography 22: 91-122. 
Brooks AP. 1999a. Pre- and post-European disturbance river morphodynamics in East Gippsland Australia. PhD thesis, Macquarie University.

Brooks AP. 1999b. Lessons for river managers from the fluvial tardis: direct insight into post-European channel changes from a near intact alluvial channel. In Proceedings of the Second Australian Stream Management Conference, Vol. 1, Rutherfurd I, Bartley R (eds). Adelaide: $121-127$.

Brooks AP. Brierley GJ. 2002. Mediated equilibrium: the influence of riparian vegetation and wood on the long term character and behaviour of a near pristine river. Earth Surface Processes and Landforms 27: 343-367.

Brooks AP, Brierley GJ. in press. Framing realistic river rehabilitation programmes in light of altered sediment transfer relationships: lessons from East Gippsland, Australia. Geomorphology.

Brooks AP, Abbe TB, Jansen JD, Taylor M, Gippel CJ. 2001. Putting the wood back into our rivers: an experiment in river rehabilitation. In Proceedings of the 3rd Austraian Stream Management Conference, Rutherfurd I, Sheldon F, Brierley G, Kenyon C (eds). Brisbane: 73-80.

Brooks AP, Brierley GJ, Millar RG. 2003. The long-term control of vegetation and woody debris on channel and floodplain evolution: insights from a paired catchment study between a pristine and a disturbed lowland alluvial river in southeastern Australia. Geomorphology 51: 7-29.

Buffington JM, Montgomery DR. 1999. Effects of hydraulic roughness on surface textures of gravel-bed rivers. Water Resources Research 35: $3507-3521$.

Church M. 1992. Channel morphology and typology. The Rivers Handbook: Hydrological and Ecological Principles, Calow P, Petts GE (eds). Blackwell: Oxford; 126-143.

Cornish PM. 1993. The effects of logging and forest regeneration on water yields in a moist eucalypt forest in New South Wales, Australia. Journal of Hydrology 150: 301-322.

Crook DA, Robertson AI. 1999. Relationship between riverine fish and woody debris: implications for lowland rivers. Marine and Freshwater Research 50: 941-953.

D’Aoust SGD, Millar RG. 1999. Large woody debris fish habitat structure performance and ballasting requirements. Watershed Restoration Program. BC Ministry of Environment Lands and Parks and Ministry of Forests: British Columbia.

Erskine WD. 1998. An Independent Assessment of the Fluvial Morphology of the Williams River and its Relevance to Future River Management Activities. NSW Department of Land \& Water Conservation: Newcastle, NSW; pp 93.

Erskine WD, White LJ. 1996. Historical Metamorphosis of the Cann River, East Gippsland, Victoria. In First National Conference on Stream Management in Australia, Rutherfurd I, Walker M (eds). CRC for Catchment Hydrology: Merrijig; 277-282.

Findlay S. 1995. Importance of surface-subsurface exchange in stream ecosystems: the hyporheic zone. Limnology and Oceanography 40(1): $159-164$.

Ford RL. 1995. Williams River. The Land and its People. R.L. Ford: Clarence Town.

Frothingham KM, Rhoads BL, Herricks EE. 2001. Stream geomorphology and fish community structure in channelised and meandering reaches of an agricultural stream. In Geomorphic Processes and Riverine Habitat, Dorava JM, Montgomery DR, Palcsak BB, Fitzpatrick FA (eds). American Geophysical Union: Washington, DC; 105-118.

Gehrke PC, Harris JH. 2001. Regional-scale effects of flow regulation on lowland riverine fish communities in New South Wales, Australia. Regulated Rivers: Research and Management 17: 369-391.

Gehrke PC, Gilligan DM, Barwick M. 2002. Changes in fish communities of the Shoalhaven River 20 years after contraction of Tallowa Dam, Australia. River Research and Applications 18: 265-286.

Gippel CJ, O’Neill IC, Finlayson BL. 1992. The Hydraulic Basis for Snag Management. Centre for Environmental Applied Hydrology, Department of Civil and Agricultural Engineering. University of Melbourne: Victoria, Australia.

Golden Software. 1999. Surfer: contouring and 3D surface mapping for scientists and engineers. Golden: Colorado.

Kahler TH. 1999. Summer movement and growth of individually marked juvenile salmonids in western Washington streams. MS thesis, University of Washington, Seattle, Washington.

Klingeman PC, Kehe SM, Owusu YA. 1984. Streambank erosion protection and channel scour manipulation using rockfill dikes and gabions. Water Resources Research Institute Technical Report WRRI-98. Oregon State University: Corvallis, OR.

Knox JC. 1977. Human impacts on Wisconsin stream channels. Annals of the Association of American Geographers 67(3): 323-342.

Lovett S (ed.). 2000. Managing snags and large woody debris. RipRap 16: 1-29.

Maddock I. 1999. The importance of physical habitat assessment for evaluating river health. Freshwater Biology 41: $373-391$.

Marsh N, Rutherfurd I, Jerie K. 1999. Large woody debris in some Australian streams: natural loading, distribution and morphological effects. In Proceedings of the Second Australian Stream Management Conference, Vol. 2, Rutherfurd I, Bartley R (eds). Adelaide: 427-432.

Maser C, Sedell JR. 1994. From the Forest to the Sea. St. Lucie Press: Delray Beach.

McDowell PF. 2001. Spatial variations in channel morphology at segment and reach scales, middle fork John Day River, Northeast Oregon. In Geomorphic Processes and Riverine Habitat, Dorava JM, Montgomery DR, Palcsak BB, Fitzpatrick FA (eds). American Geophysical Union: Washington, DC; 159-172.

Meffe GK, Sheldon AL. 1988. The influence of habitat structure on fish assemblage composition in southeastern balckwater streams. American Midland Naturalist 120: 225-240.

Miller AC, Kerr SN, Reams HE, Sartor JP. 1984. Physical modeling of spurs for bank protection. In River Meandering, Elliott CM (ed.). American Society of Civil Engineers: New York; 996-1007.

Montgomery DR, Buffington JM. 1997. Channel-reach morphology in mountain drainage basins. Geological Society of America Bulletin 109(5): 596-611.

Montgomery DR, Abbe TB, Peterson NP, Buffington JM, Schmidt K, Stock JD. 1996. Distribution of bedrock and alluvial channels in forested mountain drainage basins. Nature 381: 587-589. 
Rankin D. 1980a. River engineering for stabilising stream channels in the upper Hunter. Proceedings of a Symposium in Honour of AD. Tweedie. Department of Geography, University of Newcastle, Hunter Environment.

Rankin D. 1980b. Trees and rivers. Journal of the Soil Conservation Service of N.S.W. 36: 129-133.

Rankin D. 1982. Stabilising stream channels by river training and interaction with the environment. The Institution of Engineers. Australia Civil Engineering Transactions CE 24: 135-141.

Raven PJ, Holmes NTH, Dawson FH, Fox PJA, Everard M, Fozzard IR, Rouen KJ. 1998. River Habitat Quality: the physical character of rivers and streams in the UK and Isle of Mann. River Habitat Survey. Report 2. Environment Agency: Almondsbury, Bristol.

Reddoch AF. 1957. River control works in the non-tidal section of the Hunter River and its tributaries. Journal of the Institution of Engineers, Australia 29: 241-247.

Reddoch AF, Milston AF. 1953. Flood mitigation in New South Wales. Journal of the Institution of Engineers, Australia 25: $247-253$.

Reeves GH, Everest FH, Sedell JR. 1991. Responses of anadromous salmonids to habitat modification: how do we measure them? American Fisheries Society Symposium 10: 62-67.

Riley SC, Fausch KD. 1995. Trout population response to habitat enhancement in six northern Colorado streams. Canadian Journal of Fisheries and Aquatic Sciences 52: 34-53.

Roni P, Quinn TP. 2001. Density and size of juvenile salmonids in response to placement of large woody debris in western Oregon and Washington streams. Canadian Journal of Fisheries and Aquatic Sciences 58: 282-292.

Rutherfurd I, Jerie K, Marsh N. 2000. A Rehabilitation Manual for Australian Streams. Volumes 1 and 2. LWRRDC: Canberra.

Sear DA. 1994. River restoration and geomorphology. Aquatic Conservation: Marine and Freshwater Ecosystems 4: $169-177$.

Shields FD, Smith RH. 1992. Effects of large woody debris removal on physical characteristics of a sand-bed river. Aquatic Conservation: Marine and Freshwater Ecosystems 2: 145-163.

Shields FD, Cooper CM, Knight SS. 1995. Experiment in stream restoration. Journal of Hydraulic Engineering 121(6): 494-502.

Shields FD Jr, Knight SS, Cooper SS, Testa S. 2000. Large woody debris structures for incised channel rehabilitation. Proceedings of ASCE 2000 joint conference on water resources engineering and water resources planning and management. ASCE: Reston, VA.

Thomson JR, Taylor MP, Fryirs KA, Brierley GJ. 2001. A geomorphological framework for river characterisation and habitat assessment. Aquatic Conservation: Marine and Freshwater Ecosystems 11: 373-389.

Treadwell S, Koehn J, Bunn S. 1999. Large woody debris and other aquatic habitat. In Riparian Land Management Technical Guidelines, Volume One: Principles of Sound Management, Lovett S, Price P (eds). LWRRDC: Canberra; 79-96.

Triska FJ. 1984. Role of wood debris in modifying channel morphology and riparian areas of a large lowland river under pristine conditions: a historical case study. Verhandlungen Internationale Vereinigung für Theoretische und Angewandte Limnologie 22: $1876-1892$.

White GB. 1829. Survey of Williams River and the Located Land thereon from Singleton's Mill on the Church Reserve of Uffington to Tabbil Creek (Survey notebook). State Archives Authority of New South Wales.

White GB. 1830. Survey of Williams River and the Located Land thereon from Singleton's Mill on the Church Reserve of Uffington to Tabbil Creek. State Archives Authority of New South Wales.

White GB. 1836. Sketch of Portion of Land Applied for as a Purchase-sold to William Lowe. Department of Land and Water Conservation Plan no. H261-663.

Wolman MG. 1954. A method of sampling coarse river bed-material. Transactions of the American Geophysical Union 35: 951-956. 